\title{
Ligament Injury and Healing: A Review of Current Clinical Diagnostics and Therapeutics
}

\author{
R.A. Hauser*, E.E. Dolan, H.J. Phillips, A.C. Newlin, R.E. Moore and B.A. Woldin \\ Caring Medical \& Rehabilitation Services, S.C. 715 Lake Street, Ste. 600, Oak Park, IL 60301, USA
}

\begin{abstract}
Ligament injuries are among the most common causes of musculoskeletal joint pain and disability encountered in primary practice today. Ligament injures create disruptions in the balance between joint mobility and joint stability, causing abnormal force transmission through the joint, which results in damage to other structures in and around the joint. The long-term consequence of nonhealed ligament injury is osteoarthritis, the most common joint disorder in the world today.

Ligaments heal through a distinct sequence of cellular events that take place in three consecutive stages: an acute inflammatory phase, a proliferative or regenerative phase, and a tissue remodeling phase. The process can take months to resolve itself, and despite advances in therapeutics, many ligaments do not regain their normal tensile strength.

Various diagnostic procedures have been used to determine and assess ligament injury. Traditionally, MRI and X-rays have been the most utilized techniques; however, because ligaments do not show up clearly with these devices, there have been many false positives and negatives reported due to inconclusive or inaccurate readings. Newer technologies, such as ultrasound and digital motion X-ray, are able to provide a more detailed image of a ligament's structure and function.

Numerous strategies have been employed over the years attempting to improve ligament healing after injury or surgery. One of the most important of these is based on the understanding that monitoring early resumption of activity can stimulate repair and restoration of function and that prolonging rest may actually delay recovery and adversely affect the tissue's response to repair. Likewise, there is a shift away from the use of steroid injections and nonsteroidal antiinflammatory medications. Although these compounds have been shown effective in decreasing the inflammation and pain of ligament injuries for up to six to eight weeks, their use has been shown to inhibit the histological, biochemical, and biomechanical properties of ligament healing. For this reason their use is cautioned against in athletes who have ligament injuries. Such products are no longer recommended for chronic soft tissue injuries or for acute ligament injuries, except for the shortest possible time, if at all.

Regenerative medicine techniques, such as prolotherapy, have been shown, in both case series and clinical studies, to resolve ligament injuries of the spine and peripheral joints. More research and additional studies are needed to better assess ligament injuries and healing properties.
\end{abstract}

Keywords: Anterior cruciate ligament, joint mobility and stability, ligament healing, osteoarthritis, prolotherapy, regenerative medicine, surgery.

\section{INTRODUCTION}

Ligaments are dense bands of fibrous connective tissue that serve to join two or more bones of the musculoskeletal system. They may appear as long sheets of opaque tissue or as short thickened strips in joint capsules and can vary in size, shape, orientation, and location. Ligaments cross joints that have both wide ranges of motion and little motion and function primarily to provide stabilization of joints when at rest and during normal range of motion. Although ligaments were once thought to be inactive structures, they are in fact complex tissues that respond to many local and systemic influences [1].

*Address correspondence to this author at the Caring Medical \& Rehabilitation Services, S.C. 715 Lake Street, Ste. 600, Oak Park, IL 60301, USA; Tel: 708.848.7789; Fax: 708.848.7763;

E-mail: drhauser@caringmedical.com
Ligament injuries are among the most common causes of musculoskeletal joint pain and disability encountered in primary practice today. Ligament injuries cause disruptions in the balance between joint mobility and joint stability; this imbalance can lead to abnormal transmission of forces throughout the joint and can result in damage to other structures in and around the joint. The joints most often affected by ligament injuries are the knees, hips, shoulders, ankles, elbows, and wrists.

Ligaments are the most frequently injured tissues within a joint. About 150,000 ACL injuries occur annually in the United States, and more than 4 million knee arthroscopies are performed worldwide each year [2,3]. ACL tears rank second to ankle sprains as the leading cause of injury in college athletes, and the incidence of these tears is increasing at about $1.3 \%$ a year in this population [4]. This same trend is being observed in the pediatric population, as ACL tears are reported to be the leading cause of knee injuries in 
children, and ligaments in general, the cause of $36 \%$ of all childhood knee injuries [5].

Ligament injuries can be classified as either intrinsic or extrinsic, meaning they can occur as a result of improper motion within the joint or be caused by external factors. In athletic settings, ligament injuries are most often caused by collisions between athletes. The most common mechanisms of injury include blunt trauma, planting or pivoting, and anterior subluxation of the joint, all of which can overstretch the ligament, sometimes to the point of tearing [6-9].

Women are known to be more ligament dominant and men, more muscle dominant $[10,11]$. Consequently, sprained ligaments occur more frequently in women than in men. It has been speculated that there may also be a relationship between ligament injury and timing of the menstrual cycle, suggesting that hormonal factors may make women more prone to ligament injury [12].

While there is a vast body of knowledge available regarding the structure and function of normal ligaments, there has been limited data addressing the effects of injury on ligament structure and function in terms of the variability and unpredictable nature of ligament healing. However problematic this course of healing may be, it is likely due to the dramatic physiological and structural changes that ligaments undergo as a result of injury, as well as to the complex and dynamic cellular processes that occur during healing. These processes cause alterations in the biology and biomechanics of the injured ligament, leading to inadequate healing and tissue formation that is inferior to the tissue it has replaced. The incomplete healing and lower integrity of the new ligament tissue results in ligament laxity, predisposing the joint to further injury. This cycle of ligament injury and subsequent laxity causes joint instability, which then leads to chronic pain, diminished function, and ultimately, to osteoarthritis (OA) of the affected joint [2326].

Despite the use of numerous strategies over the years, attempts to improve ligament healing after injury have not been entirely successful. OA remains the long-term consequence of ligament injury and continues to be the most common joint disorder in the world [27]. Therefore, understanding the complex cellular processes that occur after ligament injury, as well as determining and implementing those strategies that optimize ligament restoration, are necessary steps in reducing the enormous individual and public health burden of OA.

\section{LIGAMENT STRUCTURE AND FUNCTION}

Ligaments are composed primarily of water, collagen, and various amino acids. Of the total ligament mass, approximately two-thirds is comprised of water and onethird, of solids [1]. Collagen represents approximately $75 \%$ of the dry weight of ligaments and proteoglycans, elastin, glycoproteins and other proteins make up the remaining $25 \%$. Type I collagen accounts for nearly $85 \%$ of the total collagen within ligaments, the remainder of which consists of, by weight, types III, VI, V, XI, and XIV collagen [1,28]. Microscopy of ligament tissues has shown that bundles of collagen fibers are composed of smaller fibrils arranged in parallel along the long axis of the ligament. As the collagen fibers assemble, they assume a characteristic cross-linked pattern, the formation of which appears to be specially designed because it contributes to the tremendous strength that ligaments have. Under microscope, the collagen bundles appear undulated or crimped along their length and it is believed that the crimping is present in relation to the loading capacity or tension applied to the ligaments. Upon load-bearing, certain areas of the ligament crimp, allowing the tissue to elongate without sustaining structural damage $[1,29]$. It appears that some fibers tighten or loosen depending on musculoskeletal positioning and applied forces, either of which supports the joint through various tensions and ranges of motion.

\section{TENSILE STRENGTH}

Fibroblasts, which are located between the rows of collagen fibers, produce and maintain the extracellular matrix. Recent studies suggest that fibroblast cells in normal ligaments may be capable of cell-to-cell communication, allowing the coordination of cellular and metabolic processes throughout the tissue $[1,30,31]$. Proteoglycans, which reside in the extracellular matrix, store water and contribute to the viscoelastic properties of ligaments. These viscoelastic attributes allow ligaments to progressively lengthen when under tension and return to their original shape when the tension is removed.

Ligaments attach to bones at specific sites on the bone called "insertions." Ligaments and their insertion sites can both vary in configuration; however, their geometric shape appears to relate to the manner in which the fibers within the ligament are engaged as the joint moves. The direction of joint movement determines which fibers within a particular ligament are recruited to execute a specific movement. Ligaments are covered by a vascular and cellular overlying layer called the epiligament, which is often indistinguishable from the actual ligament. The epiligament contains sensory and proprioceptive nerves, the larger percentage of which is located closer to the boney ligament insertion sites $[1,32$, 33]. When ligaments are strained, the proprioceptive nerves initiate neurological feedback signals that activate muscle contraction around the joint, allowing the body to protect and stabilize the joint after injury. Ligaments prevent excessive motion of joints by providing passive stabilization and guiding joints through normal range of motion under tensile load. In doing so, ligaments are able to transfer force to and from the skeleton while dynamically distributing the loads applied to them in order to perform specific movement patterns [34].

Although more frequently seen with tendons, ligaments can also attach to the periosteum, a tissue that plays a major role in bone growth and bone repair and has an impact on the blood supply of bone and skeletal muscle. The periosteum is composed of an outer fibrous layer and an inner layer called the cambium [35].

The outer fibrous layer is comprised of a superficial portion that is essentially inelastic and cell deficient and a deeper portion that is fibroelastic, yet also cell deficient. The superficial portion contains a matrix that is predominantly collagenous and composed of small compact bundles interspersed with elongated fibroblasts. It is the more highly 
Table 1. Demographic Data from National ACL Registry Databases

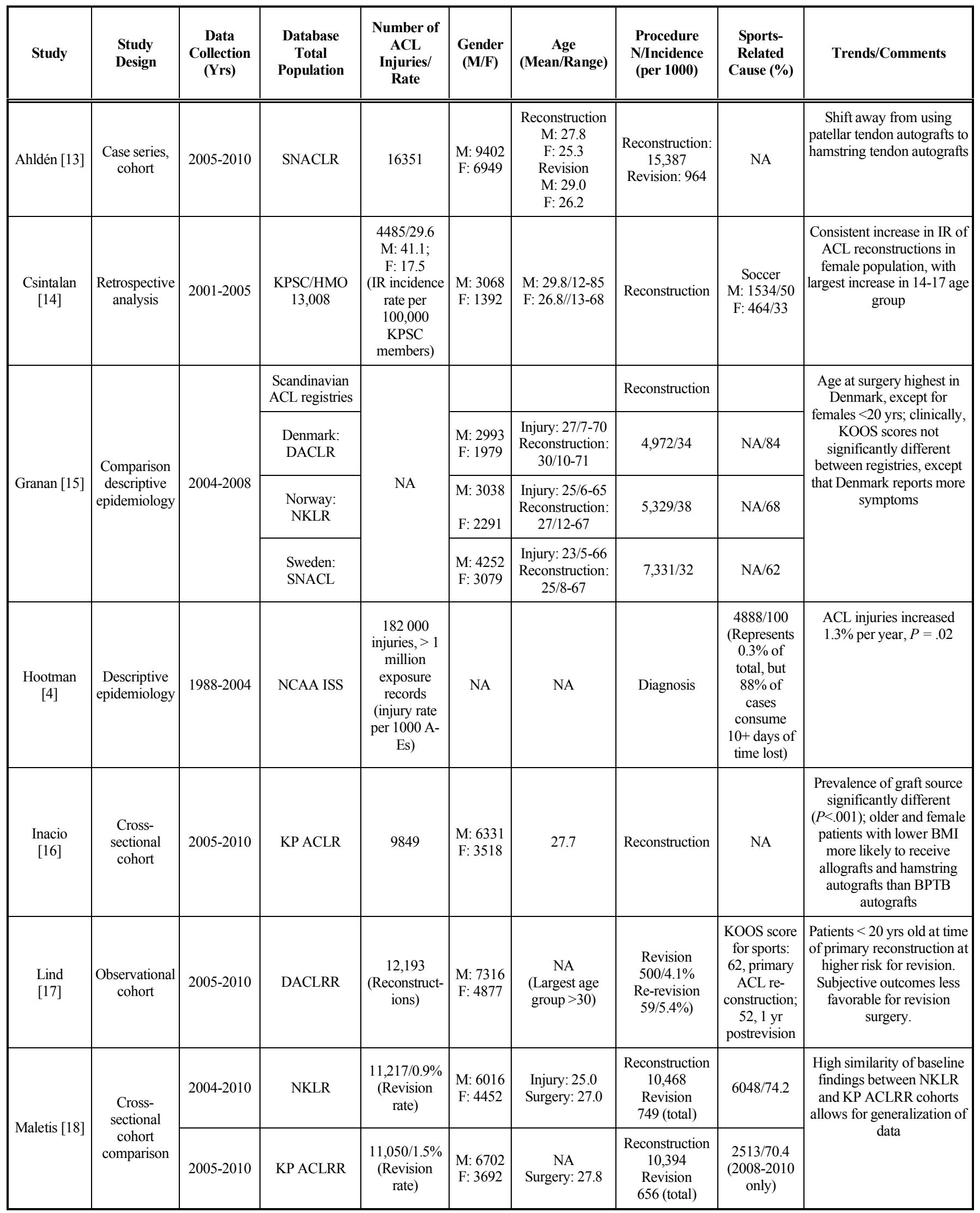




\begin{tabular}{|c|c|c|c|c|c|c|c|c|c|}
\hline Study & $\begin{array}{l}\text { Study } \\
\text { Design }\end{array}$ & $\begin{array}{c}\text { Data } \\
\text { Collection } \\
\text { (Yrs) }\end{array}$ & $\begin{array}{c}\text { Database } \\
\text { Total } \\
\text { Population }\end{array}$ & $\begin{array}{c}\text { Number of } \\
\text { ACL } \\
\text { Injuries/ } \\
\text { Rate }\end{array}$ & $\begin{array}{l}\text { Gender } \\
(\mathbf{M} / \mathbf{F})\end{array}$ & $\begin{array}{c}\text { Age } \\
\text { (Mean/Range) }\end{array}$ & $\begin{array}{l}\text { Procedure } \\
\text { N/Incidence } \\
\text { (per 1000) }\end{array}$ & $\begin{array}{c}\text { Sports- } \\
\text { Related } \\
\text { Cause (\%) }\end{array}$ & Trends/Comments \\
\hline $\begin{array}{l}\text { Nordenvall } \\
\text { [19] }\end{array}$ & $\begin{array}{c}\text { Descriptive } \\
\text { epidemiology }\end{array}$ & 2001-2009 & SNPR & $\begin{array}{l}56,659 \\
\text { (All CLs) } \\
78 \text { per } \\
100,000 \\
\text { persons }\end{array}$ & $\begin{array}{c}\text { M: } 33,778 \\
\text { F: } 22,881\end{array}$ & $\begin{array}{c}\text { Injury: } \\
\text { M: } 32.13 .1-98 \\
\text { years } \\
\text { F: } 32.44 / 1-98 \\
\text { years } \\
\text { Surgery: } \\
\text { M: } 28.34 / 5-89 \\
\text { years } \\
\text { F: } 26.08 / 5-89 \\
\text { years }\end{array}$ & $\begin{array}{c}\text { Reconstruction } \\
20,622\end{array}$ & NA & $\begin{array}{l}\text { CL injuries more } \\
\text { prevalent in males, but } \\
\text { occur at younger age in } \\
\text { females; } 1^{\text {st }} \text { study of } \\
\text { baseline epidemiology for } \\
\text { all CL injuries }\end{array}$ \\
\hline $\begin{array}{l}\text { Spindler } \\
{[20]}\end{array}$ & $\begin{array}{l}\text { Population } \\
\text { cohort }\end{array}$ & $\begin{array}{c}\text { January } 1 \text {, } \\
2002- \\
\text { October } 1 \text {, } \\
2009\end{array}$ & MOON & 448 & $\begin{array}{l}\text { M: } 201 \\
\text { F: } 174\end{array}$ & $\begin{array}{l}\text { M: 26/19-36 } \\
\text { F: 20/17-34.5 }\end{array}$ & $\begin{array}{l}\text { Reconstruction } \\
\text { M: } 179(89 \%) \\
\text { F: } 165(95 \%) \\
\text { Revision } \\
\text { M: } 22(11 \%) \\
\text { F: } 9(5 \%)\end{array}$ & 100 & $\begin{array}{l}\text { Sports-related functions } \\
\text { and knee-related QoL } \\
\text { improved after } 2 \text { and 6- } \\
\text { year follow-ups, but } \\
\text { physical activity level } \\
\text { (Marx) dropped over } \\
\text { time. }\end{array}$ \\
\hline $\begin{array}{l}\text { The MARS } \\
\text { Group [21] }\end{array}$ & $\begin{array}{l}\text { Prospective } \\
\text { longitudinal } \\
\text { cohort }\end{array}$ & $\begin{array}{c}\text { May 1, } \\
\text { 2006- } \\
\text { March 31, } \\
2009\end{array}$ & MARS & 460 & $\begin{array}{l}\text { M: } 262 \\
\text { F: } 198\end{array}$ & $26 / 12-63$ & Revision & 76 & $\begin{array}{l}\text { Most common mode of } \\
\text { failure: traumatic reinjury; } \\
\text { graft choice: allograft } \\
(54 \%) \text {, especially bone- } \\
\text { patellar tendon-bone type }\end{array}$ \\
\hline Wright [22] & $\begin{array}{l}\text { Prospective } \\
\text { longitudinal } \\
\text { cohort }\end{array}$ & $\begin{array}{c}\text { January } 1 \text {, } \\
2002- \\
\text { December } \\
31,2002\end{array}$ & MOON & 446 & $\begin{array}{c}\text { M: } 200 \\
\text { F: } 164 \\
\text { Re-revision } \\
\text { group: } \\
\text { M: } 20 ; \mathrm{F}: 9\end{array}$ & $\begin{array}{l}\text { M: } 22 \mathrm{~F}: \mathrm{NA} \\
\text { Re-revision } \\
\text { group: } \\
\text { 26/16-49 }\end{array}$ & $\begin{array}{c}\text { Revision } \\
326 \\
\text { Re-revision } \\
29\end{array}$ & NA & $\begin{array}{c}\text { Revision ACL } \\
\text { reconstruction results in a } \\
\text { worse outcome than } \\
\text { primary ACL } \\
\text { reconstruction, as shown } \\
\text { by statistically and } \\
\text { clinically significant } \\
\text { decreases in the Marx } \\
\text { activity scale. }\end{array}$ \\
\hline
\end{tabular}

Abbreviations: SNACLR: Swedish National ACL Register; NCAA ISS: National Collegiate Athletic Association Injury Surveillance System; KPSC: Kaiser Permanente Southern California; DACLRR: Danish ACL Reconstruction Registry; NKLR: Norwegian National Knee Ligament Registry; KP ACLRR: Kaiser Permanente Anterior Cruciate Ligament Registry; SNPR Swedish National Patient Register; MOON: Multicenter Orthopaedic Outcomes Network; MARS: Multicenter ACL Revision Study.

vascularized of the two substrata and contains a rich neural network. Although the superficial portion is the primary contributor to the blood supply of bone and skeletal muscle, the nerve fibers it contains generally terminate at the deeper substratum. Periosteal tendon attachments also terminate in the fibroelastic portion. Like its counterpart, the deeper portion is also highly collagenous, but is poorly vascularized. Because of its many elastic fibers, the deeper substratum is characterized by a high degree of elasticity [35].

In contrast, the cambium layer is highly cellular, composed of mesenchymal progenitor cells, differentiated osteogenic progenitor cells, fibroblasts, and osteoblasts that reside in a sparse collagenous matrix. Although the cambium appears to be the core component of the periosteum, its integrity diminishes with age. It is thickest in the fetus and becomes progressively thinner with age - so much so, that in the adult it cannot be distinguished from the overlaying fibrous layer. Vessel density and the number of periosteal fibroblasts experience the same fate, so that the periosteum at adulthood is a shell of its former self, existing only as a very thin tissue enveloping the bony structures [35].

As an enthesis, the periosteum closely wraps all bone, except for that of the articulating surfaces in joints, which is covered instead by a synovial membrane. Like other points of attachment, the periosteum can undergo trauma or become diseased, whereby recurring stress causes inflammation and often fibrosis and calcification.

Ligaments also provide joint homeostasis through their viscoelastic properties, a function that reflects the complex interactions between the collagens, proteoglycans, water, and other proteins [1, 36]. These viscoelastic properties, along with the recruitment of crimped collagen, contribute to the mechanical behavior of the structure under loading conditions. When tension is applied, ligaments deform (ie, elongate) in a non-linear manner through the recruitment of crimped collagen fibers. As the tension placed on the ligament increases, the collagen fibers progressively elongate (un-crimp), until all fibers are nearly linear (see Fig. 1). As the fibers become increasingly linear, the ligament structure becomes increasingly stiff. Varying degrees of ligament stiffness are necessary for various loads and various ranges of joint motion.

When an applied load causes all fibers to become nearly linear, the ligament continues to absorb energy until tensile failure or disruption of the tissue. Just as it does with overstretched ligaments, joint instability occurs with ligament disruptions or tears, often with more severity. Through their viscoelastic properties, ligaments are capable 


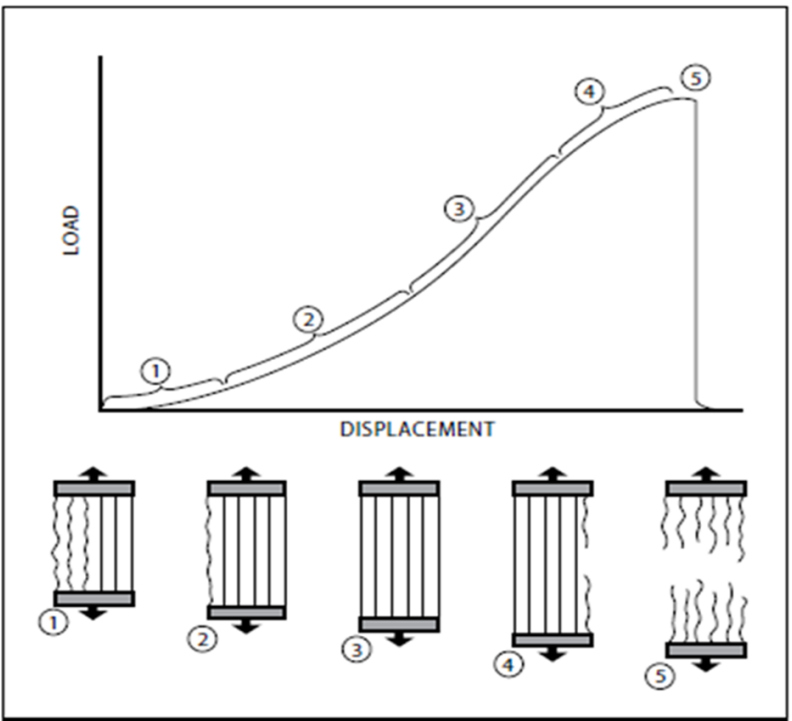

Fig. (1). Ligament structural strength graph. As the load is increased, more ligament fibers are recruited (straight lines), and the slack or creep in the fibers is removed until the entire ligament tears. The load at complete failure of the ligament represents its maximum structural strength.

of both creep and load relaxation activity and exhibit these behaviors in an attempt to prevent overstretching and disruption. Creep and relaxation action help to prevent fatigue failure of the tissue when ligaments are loaded in tension. Creep is defined as the deformation or elongation of a ligament over time under a constant load or stress. Load relaxation refers to a decrease in stress of the tissue over time when the ligament is subjected to a constant elongation [3739].

When ligaments are stretched or elongated past a certain point for a prolonged period of time, they can lose their ability to retain their original shape. When this occurs, the ligament becomes lax and unable to properly support the joint, leading to instability and pain, and eventually to OA of the joint.

\section{LIGAMENTS AS SENSORY ORGANS AND THE LIGAMENTO-MUSCULAR REFLEX}

While ligaments are predominantly known as stabilizing agents in the joints, they also have an equally important role as sensory organs involved in ligamento-muscular reflexes. As sensory organs, ligaments are able to protect the joint and prevent injury when the ligament and joint are under stress. Histological studies demonstrate that ligaments contain mechanoreceptors endowed with nerve endings called Pacinian corpuscles, Golgi tendon organs, and Ruffini endings [40]. Mechanoreceptors in ligaments of the spine and extremities respond to stimuli that provide proprioception and kinesthesia, causing activation or inhibition of muscular activities [41] (see Fig. 2). The ligamento-muscular reflex is a protective reflex emanating from sensory receptors in the ligaments to muscles, the transmission of which appears to directly or indirectly modify the load imposed on the ligament.

The ligamento-muscular reflex has been studied most extensively in the ACL, although its presence has been

\section{Ligaments As A Sensory Organ}

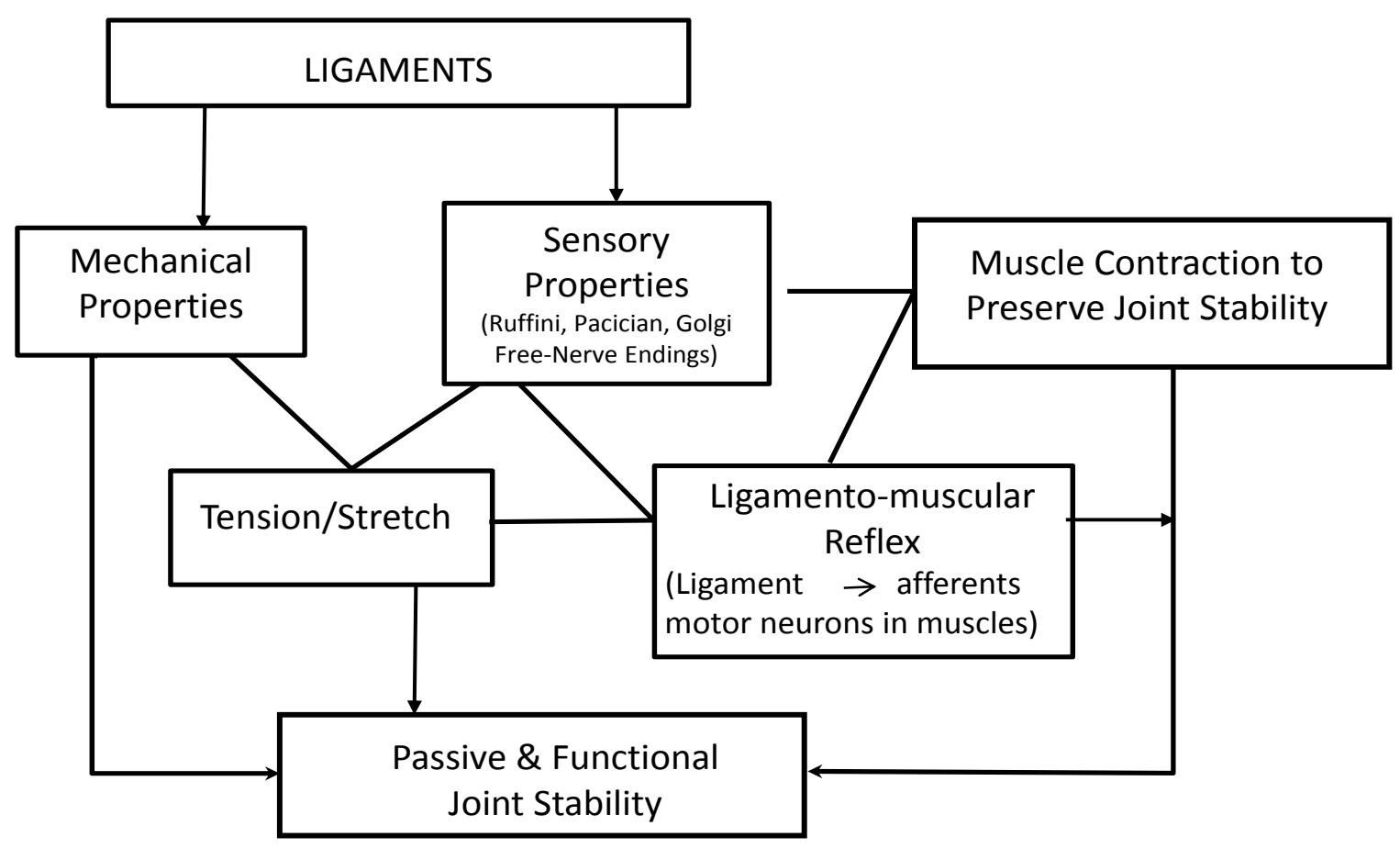

Fig. (2). Ligaments as a Sensory Organ. Basic organizational plan adapted from Johansson H, Sojka P. A Sensory Role for the Cruciate Ligaments. Clinical Orthopaedics and Related Research. 1991; (268): 161-178. 
proven to exist in most extremity joints [40]. Biomechanical studies reveal two main functions of the ACL reflex: joint stability and muscular inhibition. When the reflexes of the muscles involved are activated, they act to prevent joint distraction [42] and reduce stress on the ACL [43] and work together in an excitatory manner to create stability in the joint. More recent studies have focused on the inhibitory effects of the ligamento-muscular reflex, which protect ligaments by reducing the buildup of force in the muscles that stress them $[44,45]$. For example, the inhibitory reflex prevents force in the quadriceps which would otherwise fully flex the knee joint and cause distraction, both of which place stress on the ACL. Similar inhibitory control can also be observed in the medial collateral ligament (MCL) of the ankle. For example, the inhibitory reflex is able to prevent eversion of the foot by activating intrinsic muscles in the extremity [40]. Overall, muscular activation caused by ligament reflexes provides for the preservation of joint stability, either directly by muscles crossing the joint or indirectly by muscles not crossing the joint [40].

\section{LIGAMENT RESPONSE TO INJURY}

When ligaments are exposed to loading over an extended period of time, they increase in mass, stiffness, and load to failure [28]. However, when a ligament is overloaded, or exposed to tensions greater than the structure can sustain, the tissue fails, resulting in partial or complete ligament discontinuities, more commonly known as disruptions or tears. When these discontinuities occur, the body responds by attempting to heal the injury through a specialized sequence of overlapping, but distinct, cellular events. These events are part of the body's response to insult and occur with any soft tissue injury. They can be categorized by three consecutive phases that occur over time: the acute inflammatory phase, the proliferative or regenerative/repair phase, and the tissue-remodeling phase (see Fig. 3).

The acute inflammatory phase begins within minutes of injury and continues over the next 48 to 72 hours. During this phase, blood collects at the site of injury and platelet cells interact with certain matrix components, changing their shape and initiating clot formation. The platelet-rich fibrin clot releases growth factors that are necessary for healing and provides a platform on which many cellular events occur. Several growth factors have been identified, including Platelet-Derived Growth Factor, Transforming Growth Factor-B, Vascular Endothelial Growth Factor, and Fibroblast Growth Factor. Each of these growth factors has a specific role in the inflammatory process. For instance, Platelet-Derived Growth Factor and Transforming Growth Factor-B attract immune system cells to the area and stimulate them to proliferate; Vascular Endothelial Growth Factor aids in new blood vessel formation, which increases vascularity in injured areas; and Fibroblast Growth Factor promotes the growth of cells involved in collagen and cartilage formation. Additionally, when stimulated by growth factors, neutrophils, monocytes, and other immune cells migrate to the injured tissue where they ingest and remove debris and damaged cells produced during the inflammatory phase, thereby initiating matrix turnover.

The proliferative/repair phase begins when immune cells release various growth factors and cytokines. This initiates fibroblast proliferation signals for rebuilding of the ligament tissue matrix. The tissue formed initially appears as disorganized scar tissue, consisting of more blood vessels, fat cells, fibroblasts, and inflammatory cells than normal ligament tissue contains $[1,46]$. Over the next several weeks, fibroblast cells deposit various types of collagen, proteoglycans, glycoproteins, and other proteins into the matrix. The collagen becomes aligned with the long axis of the ligament during this time; however, the newly-formed collagen fibrils are abnormal and smaller in diameter than normal ligament tissue.

After a few weeks, the proliferative phase merges into the remodeling phase, during which time collagen maturation begins, often lasting for months to as long as years after the initial injury. With time, the tissue matrix starts to resemble normal ligament tissue; however, critical differences in matrix structure and function persist. In fact, evidence suggests that the injured ligament structure is replaced with tissue that is grossly, histologically, biochemically, and biomechanically similar to scar tissue [37, 47, 48] (see Fig. 4). As Frank et al. note, even "fully remodeled scar tissue" remains grossly, microscopically, and functionally different from normal tissues [49] (see Fig. 5).

Thus, the remodeling phase of ligament repair can continue for many months to years, during which time the

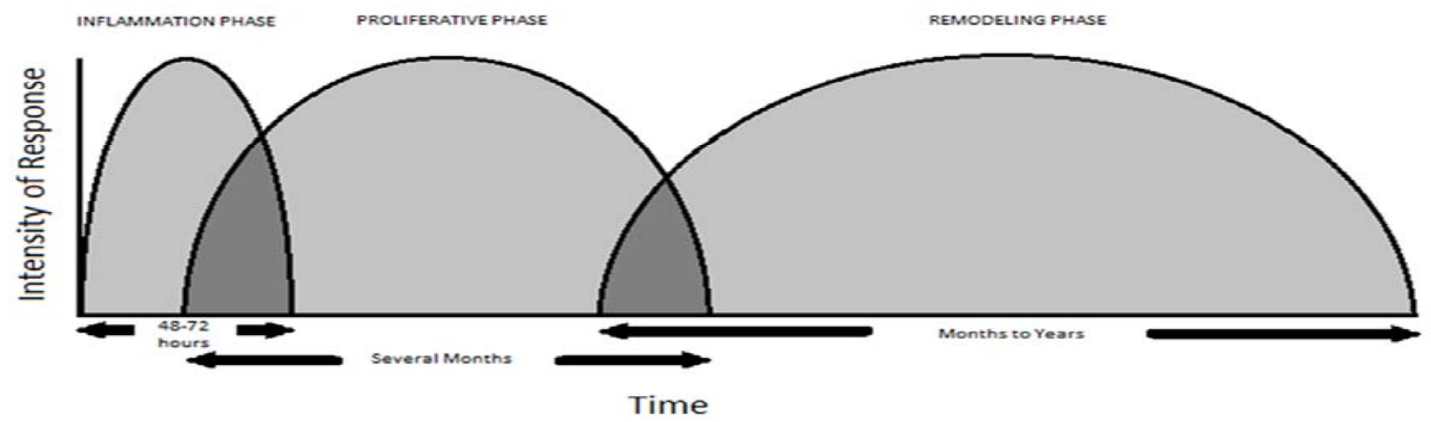

Fig. (3). The intensity and approximate amount of time in the three stages of healing: inflammatory, proliferative and remodeling phases of an injured ligament. (Adapted from Cruess et al. Healing of bone, tendon, and ligament. 1975). 


\section{Normal Ligaments}

- Bimodal (large) collagen fibrils

- Cell and matrix turnover low

- Collagen aligned

- Collagen densely packed

- High matrix-cell ratio

- Low cell density

- Mature collagen cross-links

- Primarily collagen Type I

- Primarily small proteoglycans

- Rare cell division

\section{Ligament Scars}

- Smaller collagen fibrils

- Cell and matrix turnover high

- Collagen disorganized

- Flaws between fibers

- Lower matrix-cell ratio

- Higher cell density

- Immature collagen cross-links

- More collagen III

- Larger proteoglycans

- More cell division

Fig. (4). Difference between normal ligaments and scars.

collagen and ligament matrices are continually overturned by tissue synthesis and tissue degradation. These processes provide ongoing opportunities for the ligament to adapt, either by becoming more functionally improved or degrading and failing with applied loads.

The persisting abnormalities present in the remodeled ligament matrix can have profound implications on joint biomechanics, depending on the functional demands placed on the tissue. Since remodeled ligament tissue is morphologically and biomechanically inferior to normal ligament tissue, ligament laxity results, causing functional disability of the affected joint and predisposing other soft tissues in and around the joint to further damage. Some of the identifiable differences between remodeled matrix and normal ligament matrix include alterations to proteoglycans and types of collagen, failure of collagen crosslinks to

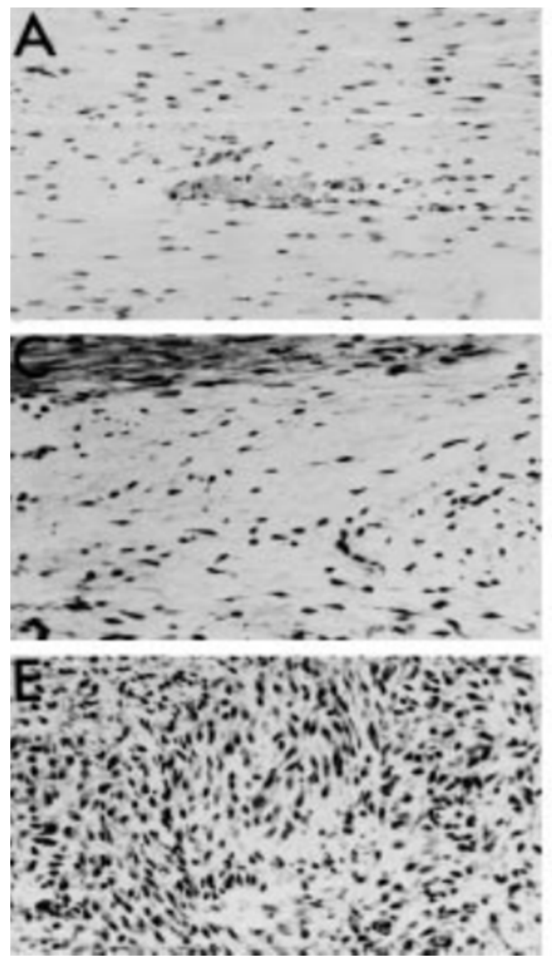

mature, persistence of small collagen fibril diameters, altered cell connections, increased vascularity, abnormal innervations, increased cellularity and the incomplete resolution of matrix flaws [1, 28, 49, 50-54]. Although research suggests that persisting collagen abnormalities may be the most critical aspect of regaining ligament tissue function, virtually all other tissue components are likely to play equally important roles in tissue function, either directly or indirectly [46, 49, 55-57].

One such tissue component is the synovial fluid, a viscous and mucinous substance that lubricates the joints. All non-weight-bearing joints are lined with synovium, the tissue that produces synovial fluid, the capsule of which is encased in a dense connective tissue layer of collagen. Synovial fluid is an ultrafiltrate of plasma which combines with hyaluronate, a mucopolysaccharide synthesized by the

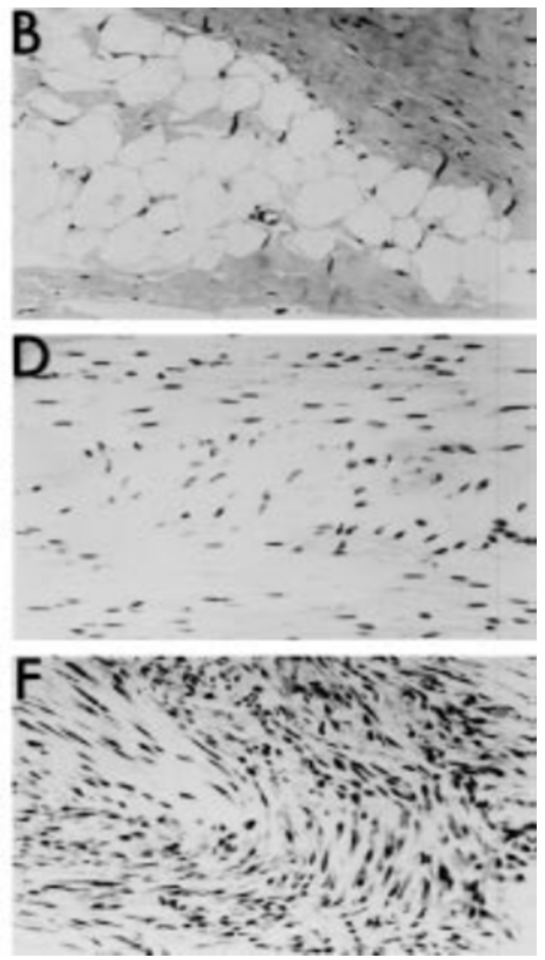

Fig. (5). Histological appearances of midsubstance 'flaws' within rabbit MCL scars, showing different types of defects within the new matri: (A) blood vessels, (B) fat cells, (C) loose collagen, (D) disorganized collagen, (E) inflammatory site with little matrix, (F) a combination of all. All Haematoxylin and Eosin stain x 125 magnification (Fig. 5 used with permission from Frank et al.). 
synovium, which sticks to the sliding surfaces to keep them apart [58].

Synovial joints consist of a soft tissue system and a cartilage-on-cartilage system, both of which require lubrication. Lubrication of the soft tissue system is dependent on hyaluronate, while lubrication of the cartilageon-cartilage system is dependent on a glycoprotein fraction of the synovial fluid. The lubricating properties of synovial fluid in the soft tissue system are directly related to the concentration and molecular weight of the hyaluronate. The function of synovial fluid is two-fold: to aid in the mechanical workings of joints by lubricating the articulating surfaces and to aid in transporting nutritional substances such as glucose to the articular cartilage [59].

Normally, the amount of synovial fluid in the joints is quite small; in the knee joint, this is usually no more than 4 $\mathrm{mL}$ of fluid. Normal synovial fluid is colorless and clear and very viscous because of its high concentration of polymerized hyaluronate. In the presence of inflammation, synovial fluid becomes yellow and cloudy and drops in viscosity [58].

Synovial fluid contains similar levels of glucose and uric acid but about one-third the level of synovial fluid protein. Synovial fluid glucose levels are typically $10 \mathrm{mg} / \mathrm{dL}$ or less below serum levels, but in the setting of joint disorders, they can decrease to as much as $20 \mathrm{mg} / \mathrm{dL}$ below normal serum levels. Uric acid levels in synovial fluid range from 6 to $8 \mathrm{mg} / \mathrm{dL}$. The normal range for synovial fluid protein is $1-3 \mathrm{~g} / \mathrm{dL}$. Patients with arthritis are known to have increased synovial fluid protein levels. Synovial fluid contains all proteins found in plasma, except for some high-molecular weight proteins such as fibrinogen which can be present in minute amounts. Fibrinogen can enter the synovial capsule during damage to the synovial membrane or as a result of trauma. Increased fibrinogen can cause clotting of the synovial fluid [58].

Vascular permeability and synovial membrane permeability are altered by inflammation, which is reflected in differences in the protein content and other changes in diseased synovial fluid. Inflammatory synovial fluid is generally characterized by alterations in its volume, decreasing viscosity, and increasing cellularity, which can affect the number of monocytes and lymphocytes, and occasionally those of erythrocytes [59].

\section{REMODELED LIGAMENTS - NOT NEARLY AS GOOD AS NEW}

As noted earlier, normal ligament tissue is primarily composed of type I collagen which is the protein responsible for the stiffness and strength of the tissue. It is the densely packed cross-linked nature of type I collagen fibrils that accounts for the stability, strength, and stiffness of normal ligaments. However, after injury, fibroblasts primarily synthesize type III collagen, not type I collagen, which it produces to a much smaller degree $[60,61]$. The abnormal cross-linking of collagen and the smaller diameters in collagen fibrils in repaired ligament tissue cause weakness in both tissue strength and tissue stiffness, often remaining for months or years after initial injury $[46,49,50,52,56,62$, 63]. In addition, evidence suggests that remodeled collagen fibrils are not packed as densely as in normal ligaments, and the remodeled tissue appears to contain materials other than collagen, such as blood vessels, fat cells, and inflammatory cell pockets, all of which contribute to its weakness $[1,46$, 49].

Most animal studies have focused on the ACL and MCL of the knee joint. In order to better understand ligament healing, many of these studies have used the MCLs of rabbits as experimental models. Such studies have shown that healing or remodeled MCLs are ultimately weaker, less stiff, and absorb less energy before failure, compared with normal MCLs $[62,64,65]$. Several studies have documented that conservatively treated injured MCLs typically regain only $40 \%$ to $80 \%$ of their structural stiffness and strength compared with normal MCLs [37, 39, 49].

On the other hand, the viscoelastic properties of injured MCLs have a better recovery, returning to within $10 \%$ to $20 \%$ of normal MCL capacity. Nevertheless, these tissues continue to exhibit greater stress relaxation, indicating that, once ligaments have sustained injury, they remain less efficient in maintaining loads than normal ligaments [49]. Remodeled MCLs also exhibit inferior creep properties, elongating more than twice as much as normal MCLs, even at low tensions [1, 49, 66, 67]. In addition, remodeled MCLs are at risk for permanent elongation because they do not appear to return to their original length, although they are able to load as quickly or as completely as normal MCLs [49]. The resultant laxity of the healing MCL leads to mechanical instability of the knee joint, which alters the contact mechanics of the joint. When the knee (or any joint) is unstable, sliding between joint surfaces increases, and the efficiency of muscles surrounding the joint decreases. This causes alterations in the load distribution of the joint, which disrupts the underlying cartilage and bone, causing wear and increasing shear. In time, this leads to osteochondral degeneration or OA [23].

Animal studies have also shown that different ligaments heal at different rates $[37,68-73]$ and that combined ligament injuries heal at a slower rate than isolated injures and produce tissue of lower quality [37, 68, 69, 74-78]. More specifically, ACL and MCL structures tend to heal at varying rates comparatively, and the quality of remodeled tissue overall among different animal species remains inferior to that of normal ligaments $[53,54,56,60,63,68,79-83]$. In fact, studies of healing ligaments have consistently shown that certain ligaments do not heal independently following rupture, and those that do heal, do so with characteristically inferior compositional properties compared with normal tissue $[64,74,84,85]$. It is not uncommon for more than one ligament to undergo injury during a single traumatic event. For instance, rabbit models with combined ACL/MCL injuries show inferior structural and material properties on examination of the healing MCL, compared with those of a model with an isolated MCL injury [68, 69, 75-78]. Some researchers believe that this may be related to the immobility of animals with painfully unstable knees or to the excessive forces placed on the healing MCL tissue when there is also damage to the ACL [37]. Why some ligaments heal spontaneously, albeit with inadequate tissue configuration, and others exhibit very poor intrinsic healing ability may be related to the specific properties of whatever ligament was injured (partial or full disruption), to what type of injury the 
ligament sustained, or to what interventions were employed after the injury.

\section{LIGAMENT LAXITY-PATHWAY TO OSTEO- ARTHRITIS}

Osteoarthritis or joint degeneration is one of the most common consequences of ligament laxity. Traditionally, the pathophysiology of OA was thought to be due to aging and wear and tear on a joint, but more recent studies have shown that ligaments play a crucial role in the development of OA $[86,87]$. OA begins when one or more ligaments become unstable or lax, and the bones begin to track improperly and put pressure on different areas, resulting in the rubbing of bone on cartilage. This causes the breakdown of cartilage and ultimately leads to deterioration, whereby the joint is reduced to bone on bone, a mechanical problem of the joint that leads to abnormality of the joint's mechanics $[23,87]$.

Hypermobility and ligament laxity have become clear risk factors for the prevalence of OA [88, 89]. The results of spinal ligament injury show that over time the inability of the ligaments to heal causes an increase in the degeneration of disc and facet joints, which eventually leads to osteochondral degeneration $[23,90]$. Studies of athletes who were followed for 5-12 years after a ligament injury have reported an early onset of $\mathrm{OA}$ in these patients and an inability for them to return to their preinjury level of activity $[23,90]$. At 10 years postinjury, $21 \%-48 \%$ of these athletes were found to have osteoarthritis, demonstrating the deleterious effects of ACL and meniscus tears [91]. A separate study following female athletes for 12 years after an ACL injury reported that $50 \%$ of the females had radiographic OA and approximately $80 \%$ had other features of OA [92]. Additionally, ligament studies on guinea pigs have shown that ligament laxity could predispose these animals to secondary as well as spontaneous OA [87, 93, 94]. Thus, ligament laxity not only leads to a higher prevalence of OA, but also increases secondary factors of OA, namely, muscle weakness, joint laxity, knee instability, and decreased function $[95,96]$.

\section{DIAGNOSIS OF LIGAMENT INJURIES}

The most important diagnostic tools in treating any bodily injury are the patient's physical symptoms. Ligament tears occur most often during strenuous physical activity and can often be identified by a distinct "pop" heard in the joint at the time of injury. Characteristic symptoms of ligament injury, whose onset may not be as instantaneous as the popping sound, include pain, swelling, instability, and the inability to withstand weight bearing.

Clinical examination techniques used to determine ligament laxity are specific to each ligament, based on their function and location. Knee injuries, for example, are evaluated using four principle tests to determine the functionality of each ligament. The anterior and posterior drawer tests are performed to test the forward and backward motion of the ACL and the posterior cruciate ligament (PCL), respectively; the valgus and varus tests assess internal and external limitations of the MCL and lateral collateral ligament (LCL), respectively [97]. Likewise, the ankle is evaluated by a number of methods, including the anterior drawer test of the anterior talofibular ligament (ATFL), an inversion test of the ATFL and calcaneofibular ligament (CFL), and an eversion test of the deltoid ligament [98].

\section{MRI - NOT ALWAYS THE BEST TOOLS OF THE TRADE}

Although magnetic resonance imaging (MRI) has been utilized as a standard for decades in diagnosing ligament sprains and tears, research suggests that it may be an unnecessary component of effectively diagnosing and treating injured ligaments. One major shortcoming in MRI evaluation of ligaments is that, while it is semi-effective at recognizing major tissue disruptions including complete ligament tears, MRI is unable to detect when ligaments are lax or stretched [99]. For instance, an injured ligament that has become stretched two or even three times its normal length appears no differently than an uninjured one because MRI only shows soft tissue contrast, not tissue quality. The sensitivity and accuracy of MRIs may also vary among ligaments themselves, which makes it impractical to rely solely on this method of imaging or use it as a gold standard [99].

Another challenge of using MRI is that it has a tendency to inaccurately diagnose false-positive ligament lesions, whereas clinical assessment and/or subsequent arthroscopy can be more accurate. In one such study comparing MRI to arthroscopy reports, Ben-Galim et al. found a false-positive rate of $47.2 \%$ for ACL tears in healthy subjects [100]. In another study, MRIs of wrists showed mild to moderate ligament injury in every case although all subjects (elite gymnasts) were asymptomatic [101].

With the possibility of false-positive results comes the risk of unnecessary treatments being performed, including surgical procedures. In one study, surgeries for $33 \%$ of subjects with positive MRIs for complete ACL tears were cancelled after arthroscopy revealed incomplete lesions [102]. In the BenGalim study previously mentioned, $37 \%$ of surgeries deemed necessary from MRI findings were later rendered unjustified [100]. Furthermore, studies comparing the accuracy of diagnosing lesions from MRI findings with those obtained by physical examination or found on arthroscopy revealed that physical examination is at least as effective, if not more effective, than MRI readings [103, 104]. These findings led Jah and colleagues to conclude, "When MRI is normal, high clinical suspicion and a skilled clinical examination are more reliable" [105]. Liu et al. echoed a similar sentiment, saying that "inexpensive tests in the clinic can allow treatment to proceed rapidly and in the most economical manner without the routine use of MRI" [106].

Imaging by diagnostic musculoskeletal ultrasound has also been utilized to view and diagnose various ligamentous injuries [107]. Sonography has the unique capability of demonstrating the current physiologic state of musculoskeletal anatomy. B-mode (brightness mode) sonography is the display of variable tissue densities along a linear grayscale. Because B-mode imaging displays the entire physiologic spectrum from active inflammation to resolved fibrosis, it is the hallmark of musculoskeletal sonography [108].

The unpredictable nature of ligament healing and the variability of the tissue's physiologic and structural processes and alterations lend themselves to sonographic 
evaluation. For instance, physiologic activity is translated into detectable changes in echodensity, and structural integrity and stability is depicted via dynamic imaging and measurement [109] (see Fig. 6). Therefore, musculoskeletal ultrasound enables clinicians to treat a patient's symptoms directly with the aid of image-guided procedures [110]. This also allows for the direct viewing of painful areas during treatment.

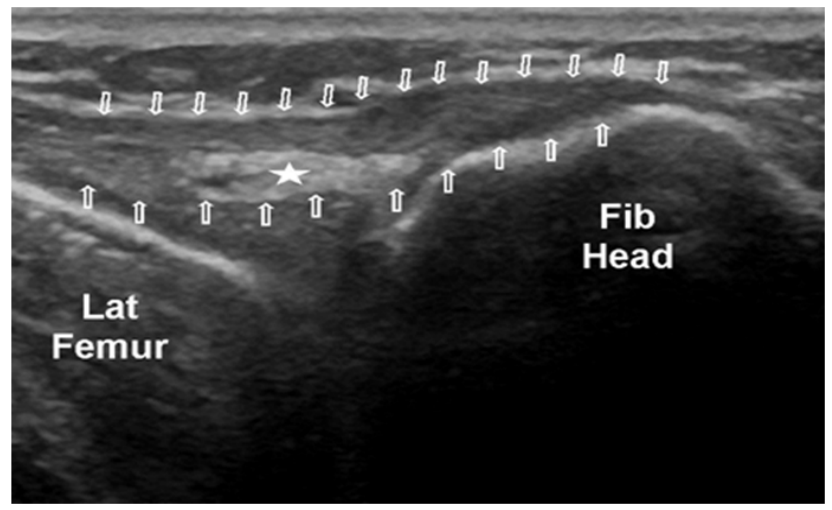

Fig. (6). Ultrasound image of an injured lateral collateral ligament (LCL).

X-rays are also used to detect changes in joint structure and signs of instability, which are often indications of ligament failure. Although X-rays are not the standard procedure for diagnosing ligament injury since the ligaments themselves are not shown, they do pick up certain structural abnormalities that are considered indicative of particular ligament injuries [111]. More recently, cineradiography such as Digital Motion X-ray (DMX) has been used as a means of visualizing the moving joint under radiography or fluoroscopy. DMX is able to spot ligament damage that static films and MRI miss and shows limitations of certain motions of the joint, providing the clinician with insight into the functionality of particular ligaments. Although it can be used to observe the motion of any mobile joint, DMX is particularly useful in diagnosing upper cervical ligament injury, especially in the case of $\mathrm{C} 1-\mathrm{C} 2$ vertebral segments which have no discs.

\section{CURRENT STRATEGIES FOR OPTIMIZING LIGAMENT REPAIR: IN SEARCH OF THE HOLY GRAIL}

As discussed earlier, ligament healing is slow and often incomplete. Joint laxity caused by ligament injury improves slowly over a period of 6 weeks to a year, after which a large percentage of patients still have objective mechanical laxity and subjective joint instability $[112,113]$. Hubbard et al. report that up to $31 \%$ of patients with ligament injuries to the ankle exhibited a positive anterior drawer sign six months after injury. Additionally, feelings of instability affected $7 \%$ to $42 \%$ of participants up to one year after injury [113].

Several strategies have been implemented over the years attempting to restore the properties of the injured ligament to preinjury status including, rest, mobilization, non-steroidal anti-inflammatory drugs, corticosteroid injections, and prolotherapy. While each of these therapies can help alleviate the subjective symptom of pain following ligament injury, they do not all necessarily contribute to the actual cellular repair and healing of ligament tissue. In fact, some of these therapies have been shown detrimental to the ligament healing process because they suppress and inhibit certain cellular processes that are required for ligament tissue repair. Others have been shown to contribute to healing through stimulation of certain cellular processes involved in the regeneration of ligament tissue.

\section{IMMOBILIZATION AND REST}

Traditionally, injured limbs have been treated with rest by splinting or casting. While immobilization of the affected joint has long been prescribed following ligament injury, it has since been discovered that healing ligaments are dramatically affected by the presence or absence of joint motion. The theory has been that rest or immobilization prevents further tissue damage in the joint by limiting its movement, and thereby, decreasing pain and swelling. It has also been thought that rest may help in improving recovery time, in decreasing functional impairment, and in reducing long-term pain. However, immobilizing a joint with a ligament injury can cause detrimental side effects, such as synovial adhesions [114], an increase in collagen degradation and a subsequent decrease in collagen synthesis [28], and a greater percentage of disorganized collagen fibrils $[62,65]$. Despite this evidence, rest and the RICE (rest, ice, compression, elevation) protocol continue to be routinely prescribed as first-line treatment for ligament, tendon, and other soft tissue injuries.

Immobilization causes ligament physiology to progressively change from an anabolic to a more catabolic state. One study [115] clearly documented that increased or decreased levels of exercise can substantially influence the strength of ligaments, as measured by collagen fiber bundle diameters in normal and repaired ligaments of dogs. The study reported that there was a direct correlation between the amount of exercise performed by the animal and the number of collagen fibrils, their arrangement, and their average thickness within the ligament.

Decreased loading of ligament tissue alters matrix turnover, so that with time, matrix degradation exceeds formation, the newly synthesized matrix becomes less well organized, and the tissue declines in stiffness and strength. Furthermore, prolonged limb immobilization decreases the content of water and glycosaminoglycans in the ligament and alters the degree of orientation of the matrix collagen fibrils within the tissue. Ultimately this causes the ligament to have less mass and strength (see Fig. 7). Decreased ligament loading also has a profound effect on the strength of the ligament-bone junction (fibro-osseous junction) because immobilization causes subperiosteal osteoclasts to resorb much of the bony inserts of the ligaments. This event causes a substantial decline in the tensile strength at the boneligament interface [116]. According to the most recent systematic reviews on research into soft tissue injuries in humans, no controlled studies appear to favor immobilization for the treatment of ligament injuries [117, 118].

\section{MOBILIZATION AND EXERCISE}

According to one systematic review by Kerkhoff et al., the authors' evaluation of research on ankle ligament injuries in 2,184 adults concluded that functional treatment involving 
motion of the affected joint was a statistically significant strategy for healing the injured ligament, compared with one immobilizing the joint. Patients who treated their ligament injuries with motion were able to return to work quicker and resume sports activity sooner than those who were immobilized, and had less objective instability, as shown by stress X-ray [117]. In another systematic review, early mobilization was found to decrease pain, swelling and stiffness, to preserve more of the ligament's range of motion, and to result in a quicker return to work [118].

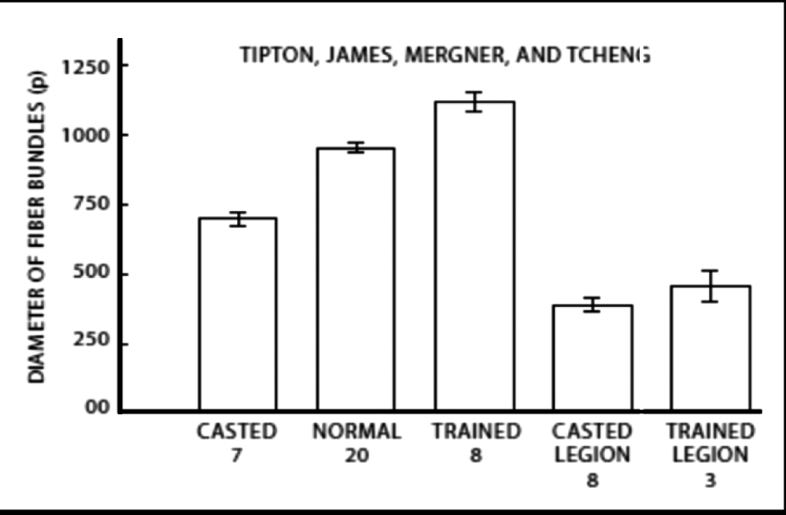

Fig. (7). Ligament fiber bundle diameters. Ligament collagen fiber diameters are increased with exercise and diminished significantly when limbs are immobilized. (Adapted from Tipton et al.).

Moreover, early controlled resumption of activity after injury, including repetitive loading on injured soft tissue structures, has been shown to have a number of beneficial effects on the recovery of injured ligaments and tendonsnamely, enhancements in both synthetic and proliferative cellular activity, increases in tissue mass and strength, improvements in matrix organization, and shifts to more normalized levels in collagen content [116]. Additionally, mobilization has been shown to benefit the injured ligament by causing it to form more connective tissue, evolving into tissue that was stronger and stiffer than its immobilized counterpart [37, 69, 70, 119]. Animal studies have had similar results, a number of which have shown that the strength of repaired ligaments is greater in animals that were allowed to continue exercising, rather than being forced to rest [120-123].

Furthermore, a structured program of rehabilitation and exercise can delay or possibly preclude ACL reconstruction. The results of a randomized controlled clinical trial recently published in the New England Journal of Medicine, compared patients undergoing structured rehabilitation plus early ACL reconstruction with those undergoing structured rehabilitation with the option of later ACL reconstruction if needed. On the basis of KOOS scores at baseline and at 2years follow-up, the study showed that a strategy of rehabilitation plus early ACL reconstruction was not superior to a strategy of rehabilitation plus optional delayed ACL reconstruction. According to the authors, early reconstruction as compared with the option of delayed reconstruction did not result in a significant improvement of the KOOS score or in any of the prespecified secondary outcomes: pain, symptoms, functions in activities of daily living and in sports and recreation, knee-related quality of life, general health status, activity level, and return to preinjury activity level at 2 years [124].

Rehabilitation following ACL surgery has been a subject of controversy. However, today most agree that rehabilitation exercises of the thigh muscles play an important role in healing. Avoidance of early quadriceps contractions after repair or reconstruction of the ACL has been advised by some, while others have advocated for early isometric quadriceps and hamstring contractions or for isotonic exercises within a limited range of motion. Since hamstrings function is believed to function synergistically with the ACL to prevent anterior displacement of the tibia on the femur, many clinicians have become advocates of rehabilitating the hamstrings when the ACL has been damaged. A Swedish study which used knee specimens removed from cadavers to measure ACL strain during simulated hamstring activity alone, quadriceps activity alone, and simultaneous quadriceps and hamstring activity reported that the hamstrings are not capable of masking the potentially harmful effects of simultaneous quadriceps contraction on freshly repaired or reconstructed ACLs unless the knee flexion angle exceeds $30^{\circ}$, concluding that hamstring exercises are not detrimental to ACL repairs or reconstruction and can be included early in the rehabilitation program after ACL surgery [43].

Overall, it appears that carefully controlled exercise plans promote healing of injured ligaments. Motion itself causes an increase in blood flow to the affected joint, providing the damaged tissue of the ligament with nutrients and metabolites necessary for its repair and healing. Under loading conditions, cells within the ligament sense tissue strains and respond by modifying the tissue. Mobilization for the treatment of soft tissue damage has also been found to decrease muscle atrophy, osteoporosis, adhesions, and joint stiffness following injury [125-131]. According to a review by Hurley and Roth, studies have indicated that, even in healthy and diseased older adults, short-term high-intensity strength training is well tolerated and helps reduce proinflammatory cytokines and knee joint loads. Despite such reports that strength training is beneficial for people with knee OA, the appropriate intensity and effect of longterm interventions remain unclear [132].

\section{NONSTEROIDAL ANTI-INFLAMMATORY DRUGS (NSAIDs)}

NSAIDs have been a mainstay treatment in ligament injuries for many years, especially in the case of acute sports injuries, but new research has shown that these antiinflammatory drugs are only mildly effective in relieving the symptoms of most muscle, ligament, and tendon injuries and are potentially deleterious to soft tissue healing [133, 134]. There are valid reasons to expect that NSAIDs might have an adverse effect on healing, since prostaglandin-induced inflammation is an early sequel in the cascade of injuryinduced events. This response normally results in the recruitment of cells into the injured area where they remove necrotic debris and initiate the healing process. However, NSAIDs are known to specifically block the cyclooxygenase enzymes which catalyze the conversion of arachidonic acid to prostaglandins which would otherwise play a significant role in ligament healing [135]. Additionally, because of the analgesic effect of NSAIDs, patients may feel no discomfort 
and ignore early symptoms of ligament injury, which could cause further damage to the ligament, and thus, delay definitive healing.

One study looked into the use of the NSAID piroxicam in the Australian military for the treatment of acute ankle sprains. While the recruits were able to resume training more rapidly, over the long-term, those in the piroxicam-treated group experienced an increase in ankle instability, as evidenced by a positive anterior drawer sign [136]. Multiple studies have been conducted on the cyclooxygenase-2 (COX-2) inhibitor class of NSAIDs, and researchers have concluded that the use of these medications inhibits ligament healing, and thus, leads to impaired mechanical strength [137-139]. Therefore, NSAIDs are no longer recommended for chronic soft tissue (ligament) injuries, and their use is cautioned in athletes who have ligament injuries. In the case of acute ligament injuries, NSAIDs should be used for the shortest period of time possible, if used at all [140, 141].

\section{CORTISONE INJECTIONS}

Corticosteroid injections have also been a long-standing treatment regimen for musculoskeletal disorders, including ligament injuries. Although steroid injections have been shown effective in decreasing inflammation and pain in ligament injuries for up to six to eight weeks, they inhibit the histological, biochemical, and biomechanical properties of ligament healing $[142,143]$. While the anti-inflammatory actions of corticosteroids stem from their ability to prevent lysosomal enzyme release, this also inhibits neutrophils and other inflammatory cells from accumulating at the injury site, as well as disrupts the synthesis of cytokines and other inflammatory mediators [144].

Mounting evidence has shown that corticosteroid injections into injured ligaments have an adverse effect on healing. For instance, corticosteroid injections into ligaments and tendons have also been known to inhibit fibroblast function and thus collagen synthesis [145-147], even to the extent of causing collagen necrosis at the injection site [148, 149]. Steroid-injected ligaments have been shown to be smaller in cross sectional area $[143,150,151]$ and weaker in integrity, as manifested by decreases in peak tensile strength and load (energy) to ligament failure [152,153]. Given the inhibitory effects corticosteroid injections have on ligament healing, many experts now caution against their use for treating ligament injuries, especially in athletes $[154,155]$.

\section{DIET AND NUTRITION}

As with any health condition or disease, diet and nutrition have an effect on the body's homeostasis, including the ligaments and their potential to heal. Joel Fuhrman, MD is a board-certified family physician, a NY Times bestselling author, and nutritional researcher who specializes in preventing and reversing disease through nutritional and natural methods. On his blog Preventing and Reversing Arthritis http://www.drfuhrman.com/disease/arthritis.aspx, Dr. Furhman discusses a major culprit in the development of OA-namely, the American diet, stating that it causes poor circulation to the microscopic blood vessels that carry oxygen and other nutrients to the joints, doing so by creating fatty streaks and plaques in the blood vessels as early as the tenth year of life. These microscopic changes, coupled with the tendency for red blood cells to adhere to the vessel lining after a rich fatty meal, impede blood flow and result in decreased oxygenation of the joints. Since the articulating bone and surrounding joint cartilage receive their nourishment and oxygen from both joint capsule fluid and small blood vessels, they become compromised when the supply of blood becomes impaired. Therefore, he advises eating a diet that is low in saturated fat and high in micronutrients, which may help stave off the occurrence and/or progression of OA.

Obesity has become a universal problem that spans all ages. Nutritionists, including the American Dietetic Association, have attributed this to an unhealthy diet full of "empty" calories and a lack of physical exercise. Numerous studies have substantiated an association between obesity and knee OA. In fact, the evidence is overwhelming - in one study, nearly twice as many female athletes with knee OA were obese, compared to a control group; in another, the risk of knee OA was almost 7 times higher in people whose body mass index (BMI) was $30 \mathrm{~kg} / \mathrm{m} 2$ or higher, compared to that of normal weight controls. From a different prospective, a loss in body mass of 5.1-kg over a 10-year period was found to reduce the odds of developing OA by more than $50 \%$. Studies have also demonstrated that weight loss not only reduces risk factors for symptomatic knee OA, but also lowers proinflammatory cytokines and adipokines thought to play a role in cartilage degradation. A meta-analysis found a strong association between obesity and OA, leading the reviewers to conclude that weight loss should be the firstchoice therapy for obese adults with knee OA [156].

Vitamins and minerals are involved in reactions that help provide the body with energy, help regulate carbohydrate, fat and protein metabolism, and promote oxygen transfer and delivery, as well as tissue repair. In a retrospective case series of chronic pain patients, Turner et al. reported that vitamin $\mathrm{D}$ inadequacy is associated with medication refractory musculoskeletal pain and neuromuscular dysfunction. The overall prevalence of vitamin D inadequacy was $26 \%$. This was most evident among patients using opioids, where there was a significant difference between vitamin $\mathrm{D}$ inadequacy and mean morphine equivalent dose $(P=0.001)$, mean duration of opioid use $(P=0.023)$, worse physical functioning $(P=0.041)$, and health perception $(P=0.003)$ [157].

Although the evidence for the benefits derived is not conclusive, other dietary supplements are often recommended for patients with osteoarthritis. For instance, chondroitin sulfate is known to reduce OA symptoms, and glucosamine sulfate, to alleviate symptoms of pain related to the disease, as well as to slow disease progression in patients knee OA [158].

\section{SURGERY}

The ultimate goal of surgery for ligament injuries, including partial and total ligament tears and ligament laxity, is to have minimal complications and retain motion in the joint while restoring its stability and function [159]. Repair surgery is intended to restore as much normal anatomy as possible to the injured ligament by either suturing the two ends of the torn ligament together or by using wire to attach it back to the bone. Reconstructive surgery is a more 
Table 2. Knee Function Measurement Tools

\begin{tabular}{|c|c|}
\hline Test Name & Outcome Measure \\
\hline \hline Fairbank & Radiological classification of OA \\
\hline International Knee Documentation Committee (IKDC) & Subjective knee evaluation form \\
\hline Kellgren- Lawrence scale & Radiological classification of OA \\
\hline Knee injury and Osteoarthritis Outcome Score (KOOS) & Subjective knee evaluation form \\
\hline KT-1000 ${ }^{\mathrm{TM}}$ Arthrometer & Evaluates anterior translation (laxity) of affected knee, as compared to normal knee \\
\hline Lysholm knee score & Assesses patient-perceived knee function and level of instability during daily activities \\
\hline Marx Scale & Rates knee activity level \\
\hline Noyes grading scale & Measures cartilage lesions \\
\hline One-leg-hop test & Erades mean level of sports activities from 0 to 10, with 10 meaning strenuous competitive \\
\hline Tegner Scale & \\
\hline
\end{tabular}

involved procedure that uses grafts or tendons from the host or a donor as a means of stabilizing the joint [160]. However, the use of reconstructive and repair surgery has become a controversial treatment option in recent years, because, even after ligaments have been surgically repaired or reconstructed, they remain weaker than the original ligaments and are unable to hold the same tensile load. It has been estimated that only $65 \%$ of patients on average return to the same level of sport activities after ACL reconstruction [161]. Nevertheless, projections indicate that knee replacement surgery is expected to see a nearly 7-fold increase between 2005 and 2030 [162].

Given this, surgical repair of ligament tears has had a relatively high degree of success in the past, albeit without its share of problems. This has become evident from the results of numerous studies which have investigated the long-term outcomes of patients who have undergone reconstruction or revision surgery after sustaining ACL injury. These studies have employed one or more of the standardized knee function tests shown in Table $\mathbf{2}$ to assess patient outcomes before and after ACL surgery.

In one early study, the results showed that $93 \%$ of athletes who had undergone repair of mid-substance tears were able to return to their sport an average of two and a half years later without their knee experiencing signs of givingway [163]. However, major registries (refer to Table 1) have accumulated data over the last two decades that more accurately reflects the current outcomes of ACL reconstruction.

All subscales of the KOOS scores at one and two-year follow ups after reconstruction recorded for 2004-2007 by the Scandinavian registries (Denmark, Norway and Sweden) improved overall from baseline, with Denmark reporting the smallest increase (57/61) in the "symptoms" category [15]. However, data at a 5-year follow up from the Swedish National Anterior Cruciate Ligament Register indicate that the only significant improvement for patients who had concomitant meniscal or chondral injuries at reconstruction was in the sport/recreation subscale. During the 5-year period, $9.1 \%$ of patients required reconstruction or revision reconstruction of the index knee [13]. In the Danish ACL reconstruction registry, the revision rate for ACL reconstruction after 5 years for was $4.1 \%$, and the rate of rerevision was higher $(5.4 \%)$, primarily the first revision was done using allograft, as opposed to autograft tissue [17]. According to the NKLR, the revision rate per follow-up year in Norway was $0.9 \%$. This was in line with the U.S. revision rate $(1.5 \%)$ from Kaiser Permanente's ACLRR database, which also reports the crude incidence rate for several adverse events/complications regarding total knee replacement for mid-2001 through 2009: revision surgery, 2.0; deep surgical site infection, 0.7; superficial surgical site infection, 0.3; deep vein thrombosis, 0.4; and pulmonary embolism, 0.5 [18].

The Multicenter Orthopaedic Outcomes Network, or MOON, as it is coined, developed validated patient-reported outcome instruments for an athletically active population which can perform multivariable analysis for identifying prognosis and modifiable predictors for both short-term and long-term outcomes after an ACL reconstruction. Follow-up was obtained at 2 years $(88 \%)$ and at 6 years $(84 \%)$. The ability to perform sports function was maintained at 6 years, but the Marx activity level continued to decline from baseline. Revision ACLR and use of allograft predicted worse outcomes according to the IKDC and both KOOS subscales. Lateral meniscus treatment at baseline was also a predictor, as was revision reconstruction which gave a lower activity level score. At 6 years post-reconstruction, patients were still able to perform sports-related functions and maintain a high knee-related quality of life similar to what they could do at their 2-year level, with the exception of their physical activity level (Marx score), which decreased over time [20].

In a paper published the following year, Wright et al, evaluated patients from the MOON database who had had revision ACL reconstructions. At 2 years, follow-up, patients with ACL revisions had a significantly worse outcome compared with those with primary ACL reconstruction only, as shown by decreases in median scores for Marx $(P=0.03)$, for IKDC $(P=0.003)$, and KOOS subscales: Knee Related Quality of Life $(P<0.001)$ and Sports and Recreation $(P=0.005)$, and Pain $(P=0.002)[22]$. 
Another database, the Multicenter ACL Revision Study (MARS), was specifically developed to allow multivariable analysis of a revision ACL reconstruction cohort to determine predictors of clinical outcomes. For those requiring revision ACLs, the most frequent mode of failure was traumatic $(32 \%)$, the most common type of graft was autograft $(70 \%)$, length of time from last reconstruction was $>2$ years, and most frequent concomitant injury was by far meniscus and/or chondral damage (90\%) [21].

These registry reports are consistent with those in the literature, which has established that ligaments tend to "fail over time", despite healing initially, and thus, become unable to hold a normal load [37, 164]. Research has shown that a ligament can fail as early as 3-5 years after surgery. In a review of the literature, Murray et al. [163] report that $94 \%$ of patients who had undergone surgery were found to have instability at a 5 -year follow-up and $72 \%$ reported they still had pain, even though 25 of the 30 patients had originally reported having a good or excellent outcome 2 years after surgery. The authors also refer to another study of patients receiving reconstructive surgery after ACL rupture, in which $17 \%$ had an overall failure rate (clinical instability or givingway) at follow-up, and $42 \%$ demonstrated laxity on clinical examination.

Many other studies have reported on the effects of surgery observed in athletes a few years after ACL tears. One study evaluating athletes 2-7 years after reconstructive surgery reported that less than $50 \%$ had been able to return to their preinjury skill level [165]. A similar study evaluating handball players who had ACL tears found that only $58 \%$ of the players who had had surgery returned to their preinjury skill or activity level compared with $82 \%$ who did not have surgery [166].

Other such studies have estimated that $10 \%$ to $30 \%$ of patients who receive ACL surgery have undesirable side effects or chronic symptoms related to joint stiffness, tendonitis or synovitis, and experience swelling, pain, muscle weakness or 'giving way' of the joint [37, 160 167]. Aside from instability, stiffness and joint pain, other complications of surgery include viral transmission of infection, bleeding, numbness, blood clotting, extensor mechanism failure, and growth plate injury. Even without the occurrence of these complications, many months of rehabilitation are required for optimal recovery [168] since the repaired or reconstructed ligament tends to remain unstable and prone to further injury. The poor woundhealing response of the ACL, especially after rupture, is well known, but the reasons for this have not been completely elucidated [163]. The consequence of such incomplete healing is degeneration of the joint and eventual osteoarthritis.

A research study followed female college athletes 12 years after an ACL rupture to assess the course of joint degeneration after surgery. Of the total, $60 \%$ of the athletes had to undergo ACL reconstructive surgery within 3 years of the initial injury. Twelve years later, $51 \%$ of study participants showed radiographic knee osteoarthritis in the injured knee, with only 7\% showing it in the uninjured knee [92]. In a 15-year follow-up study of athletes with ACL tears, including major meniscal injuries, osteoarthritis was found in only $11 \%$ of nonreconstructed knees compared to
$35 \%$ of reconstructed knees [169]. Another study reported that surgery did not reduce the prevalence of osteoarthritis in a joint, regardless of the ligament injured, nor did surgery slow the further degeneration of cartilage, often causing it to accelerate instead $[23,170]$.

While ACL reconstruction has become standard treatment for ACL tears, it is not a panacea for returning a patient's knee to normal function and does not preclude the development of OA. Overall, of all people who receive ACL surgery, only $50 \%$ are satisfied with the long-term outcome [165]. To date, there has been no evidence to demonstrate that ACL reconstruction or subsequent revision surgery can prevent OA [91]. In study after study [168, 171-174], the consensus has been that there is a substantial risk of progression to OA once an ACL injury has been sustained. One study did indicate that ACL reconstruction cannot prevent OA, but may lead to a lower prevalence of its onset and reported that the rate of osteoarthritis progression showed more severe changes in non-reconstructed patients with additional meniscus injury [175]. Another study [91] concluded that a concomitant meniscal injury had a higher risk for OA than ACL injury alone.

In their review of treatment for ACL tears, Delincé and Ghafil asked, "Could ACL reconstruction prevent osteoarthritis?" and answered their own question, stating that "At present we do not have any incontestable argument to recommend a systematic surgical reconstruction to any patient who tore his ACL to prevent further meniscus lesions and subsequent degeneration of the joint." [160] In a separate study by Neuman et al., no knee OA was found at a 15-year follow-up in patients who had been nonsurgically treated for an ACL injury [168]. Thus, the improvement of knee stability after ACL injury is a goal not limited to surgery alone; in many cases it can be realized by more conservative, and often more cost-effective, means.

\section{PROLOTHERAPY}

Prolotherapy is an injection therapy that has emerged as a viable treatment option for musculoskeletal and arthritic pain and is known by various names including proliferative therapy, regenerative injection therapy and platelet rich plasma [176]. Prolotherapy involves the injection of small amounts of various proliferant solutions (such as hypertonic dextrose, sodium morrhuate, or platelet rich plasma) into ligaments and tendons at the painful enthesis (attachment site to bone), as well as at trigger points and adjacent joint spaces; this procedure induces healing of the injured structures [177].

Histological studies of ligaments and tendons after prolotherapy injections have shown an enhanced inflammatory healing response involving fibroblastic and capillary proliferation, along with growth factor stimulation [178-180] (Fig. 8). Growth factors, including basic Fibroblast Growth Factor and Platelet-derived Growth Factor, mediate the biological processes necessary for soft tissue repair in muscles, tendons, and ligaments after acute, traumatic or overuse injury $[169,181]$. Animal research has also documented that prolotherapy-injected ligaments exhibit increases in ligament mass, in the extracellular matrix, in thickness, and in junction strength with bone [182-186]. 
Prolotherapy injections are given to the articular ligaments of the entire spine, pelvis and peripheral joints to tighten unstable joints. Case series have documented the efficacy of prolotherapy for many ligament injuries: the sacroiliac joint [187-189], lower back [190, 191], neck [192, 193], shoulder [194], elbow [195], knee [196, 197], temporomandibular joint [198, 199], and other articulations $[200,201]$.

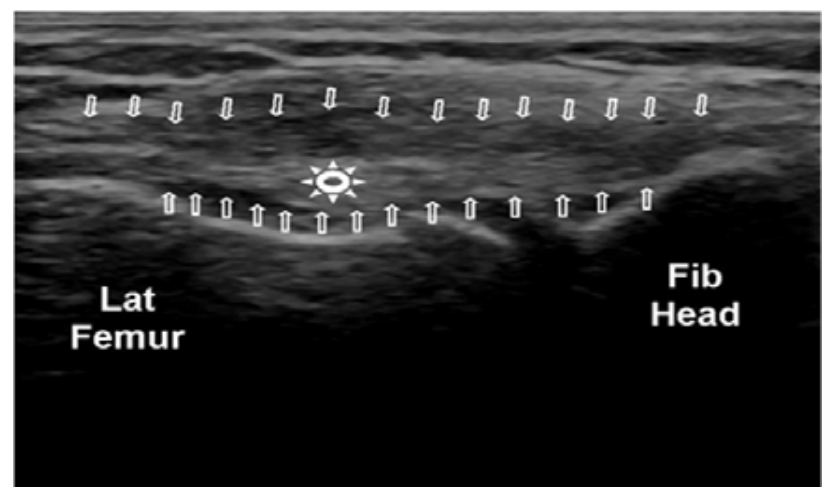

Fig. (8). Post-Prolotherapy ultrasound image of lateral collateral ligament. Longitudinal image of LCL demonstrating less hypoechoic ligament outlined by white arrows. Residual intrasubstance lesion/scar designated by the white sunburst. Compare with Fig. (6).

\section{CONCLUSION AND FUTURE DIRECTIONS}

Ligament injuries are among the most common causes of musculoskeletal joint pain and disability that physicians encounter in primary practice. Ligament injuries create disruptions in the balance between joint mobility and joint stability, causing abnormal force transmission throughout the joint which results in damage to other structures in and around the joint. Osteoarthritis is the long-term consequence of nonhealed ligament injuries and continues to be the most common joint disorder in the world. Ligaments heal through a distinct sequence of cellular events that occur in three consecutive phases: the acute inflammatory phase, the proliferative or regenerative phase and the tissue remodeling phase. Ligament healing is often slow and incomplete, as is the joint laxity caused by ligament injury which shows improvement gradually over a period of six weeks to a year after injury. However, even at this point, objective mechanical laxity and subjective joint instability are still observed in a large percentage of patients.

Numerous strategies have been employed over the years in an attempt to improve the quality of ligament healing after injury or surgery. One of the most important advances in the treatment of ligament injuries has come from the realization that controlled and early resumption of activity can stimulate repair and restoration of function, and that treatment of ligament injuries with prolonged rest may actually delay recovery and adversely affect the tissue's ability to repair itself. Likewise, the histological, biochemical, and biomechanical properties of ligament healing are inhibited by the use of steroid injections and NSAIDs, although these medications have been shown to be effective in decreasing inflammation and pain of ligament injuries over the shortterm. This has led to caution in their use, particularly in athletes who have ligament injuries; NSAIDS are no longer recommended for chronic soft tissue injuries. On the other hand, regenerative medicine techniques such as prolotherapy have shown success in several cases series involving ligament injuries of the spine and peripheral joints, but additional studies conducted in more controlled settings and with larger numbers of patients are needed in the future.

Research on ligament healing and its intricate processes continues. Many new experiments dealing with the biology and biomechanics of ligaments are providing better insights into treatments that may aid in the healing of injured ligaments and improve long-term outcomes. Gene therapy is one avenue that is being pursued as an aid in the healing and remodeling of injured ligaments, but requires further research. There has been speculation that one day it may be possible to control certain genes coding for specific mechanisms, such as decreasing decorin gene expression which would result in larger collagen fibers during the healing of ligaments [74, 202]. Another area needing further research is growth factor production. Previous research has shown that enhancing the proliferation of a growth factor has positive effects on the healing ligament, but the results appear to be short lived and quickly diluted. Because platelets are known to produce autologous growth factors, platelet rich plasma is a technique being utilized to increase the number of growth factors that can be introduced into an injured ligament [203]. Research is also needed to further examine the relationship between an individual's growth factors and the effects of decreasing or increasing their release to determine which of the growth factors are more capable of increasing the production and diameter of collagen fibers, and subsequently, would have a more positive effect on the healing ligament.

In the past few years, the field of tissue biomechanics has become more widely known and better understood, which has led to experimentation with the creation of artificial connective tissues. Another aspect of this research involves the design of an ideal scaffold, which would serve as a foundation for the injured ligament to enhance its ability to further the healing process. In vivo studies using the small intestines of animals as a scaffold are being done and have shown promising effects on enhancing tissue healing because it acts as a foundation for collagen fibers to align correctly [62]. Seeding those scaffolds with ligament fibroblasts is also being pursued as a further approach to helping ligaments align within the artificial scaffold. Through further research and improvements made to such artificial tissues and scaffolding, it is hoped that they will one day offer biomechanical properties similar to normal, healthy ligaments and help in reducing the present failure rate of repaired and reconstructed ligaments.

\section{CONFLICT OF INTEREST}

The authors confirm that this article content has no conflicts of interest.

\section{ACKNOWLEDGEMENTS}

Declared none.

\section{REFERENCES}

[1] Frank CB. Ligament structure, physiology and function. J Musculoskelet Neuronal Interact 2004; 4(2): 199-201. 
[2] American Orthopaedic Society for Sports Medicine. Available at: http://www.sportsmed.org/uploadedfiles/content/patient/sports_tips /st\%20acl\%20injury\%2008.pdf. [Accessed: 27 Nov 2012].

[3] American Academy of Orthopedic Surgeons. Knee Arthroscopy 2011. Available at: http://orthoinfo.aaos.org/topic.cfm?topic $=\mathrm{a} 00$ 299 [Accessed: 27 Nov 2012].

[4] Hootman JM, Dick R, Agel J. Epidemiology of collegiate injuries for 15 sports: summary and recommendations for injury prevention initiatives. J Athl Train 2007; 42(2): 311-9.

[5] Luhmann SJ. Acute traumatic knee effusions in children and adolescents. J Pediatr Orthop 2003; 23: 199-202.

[6] Agel J, Arendt EA, Dick R. Anterior cruciate ligament injury patterns among collegiate men and women. J Athl Train 1999; 34(3): 86-92.

[7] Ireland ML. Anterior cruciate ligament injury in female athletes: epidemiology. J Athl Train 1999; 34(2): 150-4.

[8] Schulz MS, Russe K, Weiler A, Eichhorn HJ, Strobel MJ. Epidemiology of posterior cruciate ligament injuries. Arch Orthop Trauma Surg 2003; 123: 186-91.

[9] Gianotti SM, Marshall SW, Hume PA, Bunt L. Incidence of anterior cruciate ligament injury and other knee ligament injuries: a national population-based study. J Sci Med Sport 2009; 12(6): 6227.

[10] Hasson M. Orthopedists slowly gaining insight into ACL injury risks. Orthop Today 2006; 26: 12.

[11] Scerpella TA, Stayer TJ, Makhuli BZ. Ligamentous laxity and noncontact anterior cruciate ligament tear: a gender-based comparison. Orthopedics 2005; 28: 656 .

[12] Kleinman DM. Knee laxity tied to menstrual cycle. Musculoskeletal Rep 2009 [Epub ahead of print].

[13] Ahldén M, Samuelsson K, Sernert N, Forssblad M, Karlsson J, Kartus J. Swedish National Anterior Cruciate Ligament Register: a report on baseline variables and outcomes of surgery for almost 18,000 patients. Am J Sports Med 2012; 40: 2230.

[14] Csintalan R, Inacio M, Funahash T. Incidence rate of anterior cruciate ligament reconstructions. Perm J 2008; 12(3):17-21

[15] Granan L-P, Forssblad M, Lind M, Engebretsen L. The Scandinavian ACL registries 2004-2007: baseline epidemiology. Acta Orthop 2009; 80(5): 563-7.

[16] Inacio $\mathrm{M}$, Paxton $\mathrm{E}$, Maletis $\mathrm{G}$, et al. Patient and surgeon characteristics associated with primary anterior cruciate ligament reconstruction graft selection. Am J Sports Med 2012; 40: 339.

[17] Lind $\mathrm{M}$, Menhert $\mathrm{F}$, Pedersen $\mathrm{A}$. Incidence and outcome after revision anterior cruciate ligament reconstruction: results from the Danish Registry for Knee Ligament Reconstructions. Am J Sports Med 2012; 40: 1551.

[18] Maletis G, Granan L-P, Inacio M, Funahashi T, Engebretsen L. Comparison of community-based ACL reconstruction registries in the U.S. and Norway. J Bone Joint Surg Am 2011; 93 Suppl 3(E):31-6.

[19] Nordenvall R, Bahmanyar S, Adami J, Stenros C, Wredmark T, Felländer-Tsai L. A population-based nationwide study of cruciate ligament injury in Sweden, 2001-2009: incidence, treatment, and sex differences. Am J Sports Med 2012; 40: 1808.

[20] Spindler K, Huston L, Wright R, et al. The prognosis and predictors of sports function and activity at minimum 6 years after anterior cruciate ligament reconstruction: a population cohort study. Am J Sports Med 2011; 39: 348.

[21] The MARS Group. Descriptive Epidemiology of the Multicenter ACL Revision Study (MARS) Cohort. Am J Sports Med 2010; 38 : 1979.

[22] Wright $\mathrm{R}$, Spindler $\mathrm{K}$, Huston $\mathrm{L}$, et al. Revision ACL reconstruction outcomes: MOON cohort. J Knee Surg 2011; 24:289-94.

[23] Fleming BC, Hulstyn MJ, Oksendahl HL, Fadale PD. Ligament injury, reconstruction, and osteoarthritis. Curr Opin Orthop 2005; 16 (5): 354-62.

[24] Koh J, Dietz J. Osteoarthritis in other joints (hip, elbow, foot, toes, wrist) after sports injuries. Clin Sports Med 2005; 24: 57-70.

[25] Connell DA, Pike J, Koulouris G, van Wettering N, Hoy G. MR imaging of thumb carpometacarpal joint ligament injuries. J Hand Surg Br 2004; 29: 46-54.

[26] Martou G, Veltri K, Thoma A. Surgical treatment of osteoarthritis of the carpometacarpal joint of the thumb: a systematic review. Plast Reconstr Surg 2004; 114: 1-32.
[27] Arden N, Nevitt MC. Osteoarthritis: epidemiology. Best Pract Res Clin Rheumatol 2006; 20(1): 3-25.

[28] West RV, Fu FH. Soft-tissue physiology and repair. In: Vaccaro AR, Ed. Orthopaedic Knowledge Update 8. Chapter 2, Rosemont, IL: Am Academy of Orthopaedic Surgeons, 2005; pp. 15-27.

[29] Amiel D, Constance C, Lee J. Repetitive motion disorders of the upper extremity: effect of loading on metabolism and repair of tendons and ligaments. Rosemont, Illinois: Am Acad Orthop Surg 1995; pp. 213-7.

[30] Benjamin M, Ralphs JR. The cell and developmental biology of tendons and ligaments. Int Rev Cytol 2000; 196: 85-130.

[31] Lo IK, Chi S, Ivie T, Frank CB, Rattner JB. The cellular matrix: a feature of tensile bearing dense soft connective tissues. Histol Histopathol 2002; 17: 523-37.

[32] Chowdhury P, Matyas JR, Frank CB. The "epiligament" of the rabbit medial collateral ligament: a quantitative morphological study. Connect Tissue Res 1991; 27: 33-50.

[33] Bray RC. Blood supply of ligaments: a brief overview. Orthopaedics 1995; 3: 39-48.

[34] Benjamin M, Toumi H, Ralphs JR, Bydder G, Best TM, Milz S Where tendons and ligaments meet bone: attachment sites ('entheses') in relation to exercise and/or mechanical load. J Anat 2006; 208: 471-90.

[35] Dwek JR. The periosteum: what is it, where is it, and what mimics it in its absence? Skeletal Radiol 2010; 39:319-23.

[36] Jung H-J, Fisher MB, Woo SL. Understanding normal, injured and healing ligaments and tendons: the role of biomechanics. Available at: http://www.smarttjournal.com/content/pdf/1758-2555-1-9.pdf [Accessed: 4 Oct 2012].

[37] Frank C, Shrive N, Bray R. Ligament healing: a review of some current clinical and experimental concepts. Iowa Orthop J 1992; 12: $21-8$.

[38] Akeson WH, Amiel D, Frank CB, Woo SL. Ligament biology and biomechanics. In: Finerman G, Ed. The Am Academy of Orthopaedic Surgeons Symposium on Sports Medicine, St. Louis: CV Mosby 1985; pp. 11-51.

[39] Andriacchi T, DeHaven K, Sabiston P. Ligament injury and repair. In: Woo SL, Buckwalter JA, Eds. Injury and Repair of the Musculoskeletal Soft Tissues. Park Ridge, IL: AAOS 1988; p. 103.

[40] Solomonow M. Ligaments: a source of work-related musculoskeletal disorders. J Electromyogr Kinesiol 2004; 14: 49-60.

[41] Skinner H, Barrack R. Joint position sense in the normal and pathologic knee joint. J Electromyogr Kinesiol 1991; 1: 180-90.

[42] Hirokawa S, Solomonow M, Lu Y, Lou ZP, D'Ambrosia R. Anterior posterior and rotational displacement of the tibia elicited by quadriceps contraction. Am J Sports Med 1992; 10: 299-306.

[43] Renstrom P, Arms TS, Stanwyck RJ, Johnson M, Pope MH. Strain within the ACL during hamstring and quadriceps activity. Am J Sports Med 1986; 14: 83-7.

[44] Chu D, LeBlanc R, D'Ambrosia P, D'Ambrosia R, Baratta RV, Solomonow M. Neuromuscular disorder in response to anterior cruciate ligament creep. Clin Biomech 2003; 19: 222-30.

[45] Solomonow M, Krogsgaard M. Sensorimotor control of knee stability: a review. Scand J Med Sci Sports 2001; 11: 64-80.

[46] Shrive N, Chimich D, Marchuk L, Wilson J, Brant R, Frank C. Soft-tissue "flaws" are associated with material properties of the healing rabbit medial collateral ligament. J Orthop Res 1995; 13: 923-9.

[47] Jack E.A. Experimental rupture of the medial collateral ligament of the knee. J Bone Joint Surg 1950; 32(B): 306.

[48] Fang $\mathrm{HC}, \mathrm{Hu} \mathrm{CH}$, Miltner LJ. Experimental joint sprain pathologic study. Arch Surg 1937; 35: 234.

[49] Frank C, Shrive N, Hiraoka H, Nakamura N, Kaneda Y, Hart D. Optimization of the biology of soft tissue repair. J Sci Med Sport 1999; 2(3): 190-210.

[50] Plaas AH, Wong-Palms S, Koob T, Hernandez D, Marchuk L, Frank CB. Proteoglycan metabolism during repair of the ruptured medial collateral ligament in skeletally mature rabbits. Arch Biochem Biophys 2000; 374: 35-41.

[51] Amiel D, Frank CB, Harwood FL, Akeson WH, Kleiner JB. Collagen alteration in medial collateral ligament healing in a rabbit model. Connect Tissue Res 1987; 16: 357-66.

[52] Frank C, McDonald D, Wilson J, Eyre D, Shrive N. Rabbit medial collateral ligament scar weakness is associated with decreased collagen pyridinoline crosslink density. J Orthop Res 1995; 13: 157-65. 
[53] Frank C, McDonald D, Bray D, et al. Collagen fibril diameters in the healing adult rabbit medial collateral ligament. Connect Tissue Res 1992; 27: 251-63.

[54] Lo IK, Ou Y, Rattner JP, et al. The cellular networks of normal ovine medial collateral and anterior cruciate ligaments are not accurately recapitulated in scar tissue. J Anat 2002; 200: 283-96.

[55] Bray RC, Rangayyan RM, Frank CB. Normal and healing ligament vascularity: a quantitative histological assessment in the adult rabbit medial collateral ligament. J Anat 1996; 188: 87-95.

[56] Frank C, McDonald D, Shrive N. Collagen fibril diameters in the rabbit medial collateral ligament scar: a longer term assessment. Connect Tissue Res 1997; 36: 261-9.

[57] Hildebrand KA, Frank CB. Scar formation and ligament healing. Can J Surg 1998; 41: 425-9.

[58] Mundt L, Shanahan K. Synovial fluid. Graff's textbook of routine urinalysis and body fluids. $2^{\text {nd }}$ ed. Philadelphia: Lippincott Williams \& Wilkins 2010

[59] Available at: http://cal.vet.upenn.edu/projects/saortho/chapter 86/8 6mast.htm

[60] Hsu SL, Liang R, Woo SL. Functional tissue engineering of ligament healing. Sports Med Arthrosc Rehabil Ther Technol 2010; 2: 2-10.

[61] Liu SH, Yang RS, al-Shaikh R, Lane JM. Collagen in tendon, ligament, and bone healing: a current review. Clin Orthop Relat Res 1995; 318: 265-78.

[62] Woo SL, Abramowitch SD, Kilger R, Liang R. Biomechanics of knee ligaments: injury, healing, and repair. J Biomech 2006; 39: 120 .

[63] Niyibizi C, Kavalkovich K, Yamaji T, Woo SL. Type V collagen is increased during rabbit medial collateral ligament healing. Knee Surg Sports Traumatol Arthrosc 2000; 8(5): 281-5.

[64] Weiss JA, Woo SL, Ohland KJ, Horibe S, Newton PO. Evaluation of a new injury model to study medial collateral ligament healing: primary repair versus nonoperative treatment. J Orthop Res 1991; 9(4): 516-28.

[65] Woo SL, Gomez MA, Sites TJ, Newton PO, Orlando CA, Akeson WH. The biomechanical and morphological changes in the medial collateral ligament of the rabbit after immobilization and remobilization. J Bone Joint Surg Am 1987; 69(8): 1200-11.

[66] Thornton GM, Leask GP, Shrive NG, Frank CB. Early medial collateral ligament scars have inferior creep behavior. J Orthop Res 2000; 18: 238-46

[67] Newton PO, Woo SL, Kitabayashi LR, Lyon RM, Anderson DR, Akeson WH. Ultrastructural changes in knee ligaments following immobilization. Matrix 1990; 10(5): 314-9.

[68] Bray RC, Frank C, Hennenfent B, Shrive N. Joint instability alters scar quantity and quality in healing a rabbit ligament. Orthop Trans 1990; 14: 322.

[69] Bray RC, Shrive NG, Frank CB, Chimich DD. The early effects of joint immobilization on medial collateral ligament healing in an ACL-deficient knee: a gross anatomic and biomechanical investigation in the adult rabbit model. J Orthop Res 1992; 10(2): 157-66.

[70] Hart DP. Dahners LE. Healing of the medial collateral ligaments in rats. The effects of repair, motion and secondary stabilizing ligaments. J Bone Joint Surg 1987; 69(A): 1194.

[71] Inoue M, McGurk-Burleson E, Hollis JM, Woo SL. Treatment of medial collateral ligament injury. I: The importance of anterior cruciate ligament on the varus-valgus knee laxity. Am J Sports Med 1987; 15:15

[72] Ogata K, Whiteside L, Andersen D. The intra-articular effect of various postoperative managements following knee ligament repair. an experimental study in dogs. Clin Orthop 1980; 150: 271.

[73] Piper TL, Whiteside L. Early mobilization after knee ligament repair in dogs: an experimental study. Clin Orthop 1980; 150: 277.

[74] Woo SL, Debski RE, Zeminski J, Abramowitch SD, Saw SS, Fenwick JA. Injury and repair of ligaments and tendons. Annu Rev Biomed Eng 2000; 2: 83-118.

[75] Fetto JF, Marshall JL. Medial collateral ligament injuries of the knee: a rationale for treatment. Clin Orthop 1978; 132: 206-18.

[76] Warren RF, Marshal JL. Injuries of the anterior cruciate and medial collateral ligaments of the knee. a long term follow-up of 86 cases. Part II. Clin Orthop 1978; 136: 198-211.

[77] Yamaji T, Levine RE, Woo SL, Niyibizi C, Kavalkovich KW, Weaver-Green CM. Medial collateral ligament healing one year after a concurrent medial collateral ligament and anterior cruciate ligament injury: an interdisciplinary study in rabbits. J Orthop Res 1996; 14: 223-7.

[78] Ohno K, Pomaybo AS, Schmidt CC, Levine RE, Ohland KJ, Woo SL. Healing of the medial collateral ligament after a combined medial collateral and anterior cruciate ligament injury and reconstruction of the anterior cruciate ligament: comparison of repair and non-repair of medial collateral ligament tears in rabbits. J Orthop Res 1995; 13: 442-9.

[79] Scheffler SU, Clineff TD, Papageorgiou CD, Debski RE, Ma CB, Woo SL. Structure and function of the healing medial collatera ligament in a goat model. Ann Biomed Eng 2001; 29(2): 173-80.

[80] Frank C, Woo SL, Amiel D, Harwood F, Gomez M, Akeson W. Medial collateral ligament healing. A multidisciplinary assessment in rabbits. Am J Sports Med 1983; 11(6): 379-89.

[81] Abramowitch SD, Papageorgiou CD, Debski RE, Clineff TD, Woo SL. A biomechanical and histological evaluation of the structure and function of the healing medial collateral ligament in a goat model. Knee Surg Sports Traumatol Arthrosc 2003; 11(3): 155-62.

[82] Marshall JL, Olsson SE. Instability of the knee. a long-term experimental study in dogs. J Bone Joint Surg 1971; 53(A): 1561.

[83] O'Donoghue DH, Frank GR, Jeter GL, Johnson W, Zeiders JW, Kenyon R. Repair and reconstruction of the anterior cruciate ligament in dogs. Factors influencing long-term results. J Bone Joint Surg 1971; 53(A): 710

[84] Woo SL, Inoue M, McGurk-Burleson E, Gomez MA. Treatment of the medial collateral ligament injury. II: Structure and function of canine knees in response to differing treatment regimens. Am J Sports Med 1987; 15: 22-9.

[85] Frank CB, Hart DA, Shrive NG. Molecular biology and biomechanics of normal and healing ligaments: a review. Osteoarthr Cartil 1999; 7: 130-40.

[86] McGonagle D, Tan AL, Grainger AJ, Benjamin M. Heberden's nodes and what Heberden could not see: the pivotal role of ligaments in the pathogenesis of early nodal osteoarthritis and beyond. Rheumatology 2008; 47(9): 1278-85.

[87] Brandt KD, Radin EL, Dieppe PA, van de Putte L. Yet more evidence that osteoarthritis in not a cartilage disease. Ann Rheum Dis 2006; 65: 1261-4.

[88] Loeser R. Molecular mechanisms of cartilage destruction: Mechanics, inflammatory mediators, and aging collide. Arthritis Rheum 2006; 54(5): 1357-60.

[89] Kirk J, Ansell BM, Bywaters EGL. The hypermobility syndromemusculoskeletal complaints associated with generalized joint hypermobility. Ann Rheum Dis 1967; 26: 419-25.

[90] Panjabi MM. A hypothesis of chronic back pain: ligament subfailure injuries lead to muscle control dysfunction. Eur Spine J 2006; 15(5): 668-76.

[91] Øiestad BE, Engebretsen L, Storheim K, Risberg MA. Knee osteoarthritis after anterior cruciate ligament injury. Am J Sports Med 2009; 37(7): 1434-343.

[92] Lohmander LS, Ostenberg A, Englund M, Roos H. High prevalence of knee osteoarthritis, pain, and functional limitations in female soccer players twelve years after anterior cruciate ligament injury. Arthritis Rheum 2004; 50(10): 3145-52.

[93] Ameye LG, Young MF. Animal models of osteoarthritis: lessons learned while seeking the 'holy grail'. Curr Opin Rheumatol 2006 18(5): 537-47.

[94] Quasnichka HL, Anderson-MacKenzie JM, Tarlton JF, Sims TJ, Billingham ME, Bailey AJ. Cruciate ligament laxity and femoral intercondylar notch narrowing in early-stage knee osteoarthritis. Arthritis Rheum 2005; 52(10): 3100-9.

[95] Van Der Esch M, Steultjens M, Knol DL, Dinant H, Dekker J. Joint laxity and the relationship between muscle strength and functional ability in patients with osteoarthritis of the knee. Arthritis Care Res 2006; 55(6): 953-9.

[96] Schmitt LC, Fitzgerald GK, Reisman AS, Rudolph KS. Instability, laxity, and physical function in patients with medial knee osteoarthritis. Phys Ther 2008; 88(12): 1506-16.

[97] Malanga G, Andrus S, Nadler S, McLean J. Physical examination of the knee: a review of the original test description and scientific validity of common orthopedic tests. Arch Phys Med Rehabil 2003; 84: 592-603.

[98] Fong D, Chan YY, Mok KM, Yung PSH, Chan KM. Understanding acute ankle ligamentous sprain injury in sports Sports Med Arthrosc Rehabil Ther Technol 2009; 1: 14. 
[99] Crawford R, Walley G, Bridgman S, Maffulli N. Magnetic resonance imaging versus arthroscopy in the diagnosis of knee pathology, concentrating on meniscal lesions and ACL tears: a systematic review. Br Med Bull 2007; 84(1): 5-23.

[100] Ben-Galim P, Steinberg EL, Amir H, Ash N, Dekel S, Arbel R. Accuracy of magnetic resonance imaging of the knee and unjustified surgery. Clin Orthop Related Res 2006; 447:100-4.

[101] Fredericson M, Ho C, Jennings F, et al. Magnetic resonance image abnormalities in the shoulder and wrist joints of asymptomatic elite athletes. PM R 2009; 1: 107-16.

[102] Tsai KJ, Chiang H, Jiang CC. Magnetic resonance imaging of anterior cruciate ligament rupture. BMC Musculoskelet Disord 2004; 5: 21.

[103] Rayan F, Bhonsle S, Shukla DD. Clinical, MRI, and arthroscopic correlation in meniscal and anterior cruciate ligament injuries. Int Orthop 2009; 33: 129-32.

[104] Rose NE, Gold SM. A comparison of accuracy between clinical examination and magnetic resonance imaging in the diagnosis of meniscal and anterior cruciate ligament tears. Arthroscopy 1996; 12(4): 398-405.

[105] Esmaili Jah AA, Keyhani S, Zarei R, Moghaddam AK. Accuracy of MRI in comparison with clinical and arthroscopic findings in ligamentous and meniscal injuries of the knee. Acta Orthop Belg 2005; 71: 189-96.

[106] Liu SH, Osti L, Henry M, Bocchi L. The diagnosis of acute complete tears of the anterior cruciate ligament. J Bone Joint Surg 1995; 77-B: 568-86.

[107] Lento PH, Primack S. Advances and utility of diagnostic ultrasound in musculoskeletal medicine. Curr Rev Musculoskelet Med 2008; 1(1): 24-31.

[108] Lutz HT, Buscarini E, Eds. WHO Manual of Diagnostic Ultrasound $2^{\text {nd }}$ ed, vol 1, Geneva, Switzerland: WHO Press 2011; p. 12.

[109] Mei-Dan O, Kots E, Barchilon V, Massarwe S, Nyska M, Mann G. A dynamic ultrasound examination for the diagnosis of ankle syndesmotic injury in professional athletes. Am J Sports Med 2009; 37(5): 1009-16.

[110] Torriani M, Kattapuram SV. Musculoskeletal ultrasound: an alternative imaging modality for sports related injuries. Top Magn Reson Imaging 2003; 14(1): 103-12.

[111] Alford JW, Back BR. Managing ACL tears: evaluations and diagnosis. J Musculoskelet Med 2004; 21: 381-90.

[112] Hintermann B. Biomechanics of the unstable ankle joint and clinical implications. Med Sci Sports Exerc 1999; 31(7 Suppl):S459-69

[113] Hubbard TJ, Hicks-Little CA. Ankle ligament healing after an acute ankle sprain: an evidence-based approach. J Athl Train 2008; 43(5): 523-9.

[114] Woo SL, Matthews JV, Akeson WH, Amiel D, Convery FR. Connective tissue response to immobility. Correlative study of biomechanical and biochemical measurements of normal and immobilized rabbit knees. Arthritis Rheum 1975; 18: 257-64.

[115] Tipton CM, James SL, Mergner W, Tcheng TK. Influence of exercise on strength of medial collateral knee ligaments of dogs. Am J Physiol 1970; 216(3): 894-902.

[116] Buckwalter JA. Activity $v s$ rest in the treatment of bone, soft tissue, and joint injuries. Iowa Orthop J 1995; 15: 29-42.

[117] Kerkhoffs GMMJ, Rowe BH, Assendelft WJJ, Kelly KD, Struijs PAA, van Dijk CN. Immobilisation and functional treatment for acute lateral ankle ligament injuries in adults. Cochrane Database Syst Rev 2002; (3): DOI: 10.1002/14651858.CD003762.

[118] Nash CE, Mickan SM, Del Mar CB, Glasziou PP. Resting injured limbs delays recovery: a systematic review. J Fam Pract 2004; 53(9): 706-12.

[119] Vailas AC, Tipton CM, Matthes RD, Gart M. Physical activity and its influence on the repair process of medial collateral ligaments. Connect Tissue Res 1981; 9: 25.

[120] Goldstein WM, Barmada R. Early mobilization of rabbit medial collateral ligament repairs: biomechanic and histologic study. Arch Phys Med Rehabil 1984; 65(5): 239-42.

[121] Walsh S, Frank CB, Shrive N, Hart D. Knee immobilization inhibits biomechanical maturation of the rabbit medial collateral ligament. Clin Orthop Relat Res 1993; 297: 253-61.

[122] Thornton GM, Johnson JC, Maser RV, Marchuk LL, Shrive NG, Frank CB. Strength of medial structures of the knee joint are decreased by isolated injury to the medial collateral ligament and subsequent joint immobilization. J Orthop Res 2005; 23(5): 1191-8.
[123] Thornton GM, Shrive NG, Frank CB. Healing ligaments have decreased cyclic modulus compared to normal ligaments and immobilization further compromises healing ligament response to cyclic loading. J Orthop Res 2003; 21(4): 716-22.

[124] Frobell RB, Roos EM, Roos HP, Ranstam J, Lohmander LS. A randomized trial of treatment for acute anterior cruciate ligament tears. N Engl J Med 2010; 363(4): 331-42.

[125] Pneumaticos SG, McGarvey WC, Mody DR, Trevino SG. The effects of early mobilization in the healing of Achilles tendon repair. Foot Ankle Int 2000; 21(7): 551-7.

[126] Gelberman RH, Menon J, Gonsalves M, Akeson WH. The effects of mobilization on the vascularization of healing flexor tendons in dogs. Clin Orthop 1980; 153: 283-9.

[127] Kannus P. Immobilization or early mobilization after an acute soft tissue injury. Physician Sports Med 2000; 28: 58-63.

[128] Halikis MN, Manske PR, Kubota H, Aoki M. Effect of immobilization, immediate mobilization and delayed mobilization of the resistance to digital flexion using a tendon injury model. $\mathrm{J}$ Hand Surg Am 1997; 22(A): 464-72.

[129] Romanelli DA, Almekinders LC, Mandelbaum BR. Achilles rupture in the athlete: current science and treatment. Sports Med Arthrosc Rev 2000; 8: 377-86.

[130] Viidik A. The effect of training on the tensile strength of isolated rabbit tendons. Scand J Plastic Reconstr Surg 1967; 1: 141-7.

[131] Peacock E. Biological principles in the healing of long tendons. Surg Clin North Am 1965; 45: 461-76.

[132] Hurley BF, Roth SM. Strength training in the elderly: effects on risk factors for age-related diseases. Sports Med 2000; 30(4): 24968.

[133] Mehallo CJ, Drezner JA, Bytomski JR. Practical management: nonsteroidal anti-inflammatory drug use in athletic injuries. Clin J Sports Med 2006; 16: 170-4.

[134] Dahners LE, Mullis BH. Effects of nonsteroidal anti-inflammatory drugs on bone formation and soft-tissue healing. J Am Acad Orthop Surg 2004; 12: 139-43.

[135] Radi ZA, Khan NK. Effects of cyclooxygenase inhibition on bone, tendon, and ligament healing. Inflamm Res 2005; 54: 358-66.

[136] Slatyer MA, Hensley MJ, Lopert R. A randomized controlled trial of piroxicam in the management of acute ankle sprain in Australian regular army recruits. Am J Sports Med 1997; 25: 544-53.

[137] Elder CL, Dahners LE. Weinhold PS. A cyclooxygenase- 2 inhibitor impairs ligament healing in the rat. Am J Sports Med 2001; 29: 801-10.

[138] Warden SJ, Avin KG, Beck EM, DeWolf ME, Hagemeir MA, Martin KM. Low-intensity pulsed ultrasound accelerates and a nonsteroidal anti-inflammatory drug delays knee ligament healing. Am J Sports Med 2006; 34: 1094-102.

[139] Warden SJ. Cyclo-oxygenase-2 inhibitors: beneficial or detrimental for athletes with acute musculoskeletal injuries? Sports Med 2005; 35: 271-83.

[140] Ziltener JL, Leal S, Fournier PE. Non-steroidal anti-inflammatory drugs for athletes: an update. Ann Phys Rehabil Med 2010; 53: 278-82.

[141] Paoloni JA, Milne C, Orchard J, Hamilton B. Non-steroidal antiinflammatory drugs in sports medicine: guidelines for practical but sensible use. Br J Sports Med 2009; 43: 863-5.

[142] Mackie JW, Goldin B, Foss ML, Cockrell JL. Mechanical properties of rabbit tendons after repeated anti-inflammatory steroid injections. Med Sci Sports 1974; 6: 198-202.

[143] Walsh WR, Wiggins PD, Fadale PD, Ehrlich MG. Effects of a delayed steroid injection on ligament healing using a rabbit medial collateral ligament model. Biomaterials 1995; 16: 905-10.

[144] Shapiro PS, Rohde RS, Froimson MI, Lash RH, Postak PA, Greenwald S. Corticosteroid or ketorolac exposure on histologic and biomechanical properties of rabbit tendon and cartilage. Hand 2007; 4: 165-72.

[145] Berliner DL, Nabors CJ. Effects of corticosteroids on fibroblast functions. Res J Reticuloendothel Soc 1967; 4: 284-313.

[146] Kapetanos G. The effect of the local corticosteroids on the healing and biomechanical properties of the partially injured tendon. Clin Orthop Relat Res 1982; 163: 170-9.

[147] Oxlund H. The influence of a local injection of cortisol on the mechanical properties of tendons and ligaments and the indirect effect on skin. Acta Orthop Scand 1980; 51: 231-8. 
[148] Balasubramaniam P, Prathap K. The effect of injection of hydrocortisone into rabbit calcaneal tendons. J Bone Joint Surg 1972; 54B: 729-34.

[149] Scutt N, Rolf CG, Scutt A. Glucocorticoids inhibit tenocyte proliferation and tendon progenitor cell recruitment. J Orthop Res 2006; 24: 173-82.

[150] Wiggins ME, Fadale PD, Ehrlich MG, Walsh WR. Effects of local injection of corticosteroids on the healing ligaments. A follow-up report. J Bone Joint Surg 1995; 77A: 1682-91.

[151] Wiggins M, Fadale PD, Barrach H, Ehrlich MG, Walsh WR. Healing characteristics of a type- 1 collagenous structure treated with corticosteroids. Am J Sports Med 1994; 22: 279-88.

[152] Noyes FR, Grood ES, Nussbaum NS, Cooper SM. Effect of intraarticular corticosteroids on ligament properties. A biomechanical and histological study in rhesus knees. Clin Orthop Relat Res 1977; 123: 197-209.

[153] Nichols AW. Complications associated with the use of corticosteroids in the treatment of athletic injuries. Clin J Sports Med 2005; 15: 370-5.

[154] Fredberg U. Local corticosteroid injection in sport: review of literature and guidelines for treatment. Scand J Med Sci Sports 1997; 7: 131-9.

[155] Fadale PD, Wiggins ME. Corticosteroid injections: Their use and abuse. J Am Acad Orthop Surg 1994; 2: 133-40.

[156] Messier SP. Diet and exercise for obese adults with knee osteoarthritis. Clin Geriatr Med 2010; 26: 461-77.

[157] Turner MK, Hooten WM, Schmidt JE, Kerkvliet JL, Townsend CO, Bruce BK. Prevalence and clinical correlates of vitamin D Inadequacy among patients with chronic pain. Pain Med 2008; 9: 8 979-84.

[158] Gregory PJ, Sperry M, Amy friedmdman wilson. Dietary supplements for osteoarthritis. Am Fam Physician 2008; 77(2): 177-84.

[159] Lynch SA, Renstrom PAFH. Treatment of acute lateral ankle ligament rupture in the athlete: conservative versus surgical treatment. Sports Med 1999; 27(1): 61-71.

[160] Delincé P, Ghafil D. Anterior cruciate ligament tears: conservative or surgical treatment? a critical review of the literature. Knee Surg Sports Traumatol Arthrosc 2012; 20:48-61.

[161] Kurtz S, Ong K, Lau E, Mowat F, Halpern M. Projections of primary and revision hip and knee arthroplasty in the United States from 2005 to 2030. J Bone Joint Surg Am 2007; 89(4): 780

[162] Murray MM, Martin SD, Martin TL, Spector M. Histological changes in the human anterior cruciate ligament after rupture. J Bone Joint Surg 2000; 82-a(10): 1387-97.

[163] Levy BA, Dajani KA, Morgan JA, Shah JP, Dahm DL, Stuart MJ. Repair versus reconstruction of the fibular collateral ligament and posterolateral corner in the multiligament-injured knee. Am J Sports Med 2010; 38(4): 804-9.

[164] O'Donoghue DH. Surgical treatment of fresh injuries to the major ligaments of the knee. J Bone Joint Surg 1950; 32: 721-38.

[165] Ardern CL, Taylor NF, Feller JA, Webster EK. Return-to-sport outcomes at 2 to 7 years after anterior cruciate ligament reconstruction surgery. Am J Sports Med 2012; 40: 41.

[166] Millett PJ, Wickiewicz TL, Warren RF. Motion loss after ligament injuries to the knee. Part I: causes. Am J Sports Med 2001; 29(5): 664-75.

[167] Myklebust G, Holm I, Maehlum S, Engebretsen L, Bahr R. Clinical, functional, and radiologic outcome in team handball players 6 to 11 years after anterior cruciate ligament injury. Am J Sports Med 2003; 31(6): 981-9.

[168] Neuman P, Englund M, Kostogiannis I, Fridén T, Roos H, Dahlberg LE. Prevalence of tibiofemoral osteoarthritis 15 years after nonoperative treatment of anterior cruciate ligament injury. Am J Sports Med 2008; 36: 1717-25.

[169] Creaney L, Hamilton B. Growth factor delivery methods in the management of sports injuries: the state of play. Br J Sports Med 2008; 42: 314-20.

[170] Chaudhari AM, Briant PL, Bevill SL, Koo S, Andriacchi TP. Knee kinematics, cartilage morphology, and osteoarthritis after ACL surgery. Med Sci Sports Exerc 2008; 40(2): 215-22.

[171] Struewer J, Manfred Frangen T, Ishaque B, et al. Knee function and prevalence of osteoarthritis after isolated anterior cruciate ligament reconstruction using bone-patellar tendon-bone graft: long-term follow-up. Int Orthop (SICOT) 2012; 36:171-7.
[172] van der Hart CP, van den Bekerom MP, Patt TW. The occurrence of osteoarthritis at a minimum of ten years after reconstruction of the anterior cruciate ligament. J Orthop Surg Res 2008; 3:24.

[173] Murray JR, Lindh AM, Hogan NA, et al. Does anterior cruciate ligament reconstruction lead to degenerative disease? thirteen-year results after bone-patellar tendon-bone autograft. Am J Sports Med 2012; 40: 404-14.

[174] Wilson DR, McWalter EJ, Johnston JD. The measurement of joint mechanics and their role in osteoarthritis genesis and progression. Rheum Dis Clin North Am 2008; 34(3): 605-22.

[175] Mihelic R, Jurdana H, Jotanovic Z, Madjarevic T, Tudor A. Longterm results of anterior cruciate ligament reconstruction: a comparison with non-operative treatment with a follow-up of 17-20 years. Int Orthop 2011; 35: 1093-7.

[176] Sánchez M, Anitua E, Orive G, Mujika I, Andia I. Platelet-rich therapies in treatment of orthopaedic sport injuries. Sports Med 2009; 39: 345-54.

[177] Kim SR, Stitik TP, Foye PM, Greenwald BD, Campagnolo DI. Critical review of prolotherapy for osteoarthritis, low back pain and other musculoskeletal conditions: A physiatrist perspective. Am J Phys Med Rehabil 2004; 83: 379-89.

[178] Maynard JA, Pedrini VA, Pedrini-Mille A, Romanus B, Ohlerking F. Morphological and biomechanical effects of sodium morrhuate on tendons. J Orthop Res 1985; 3: 236-48.

[179] Hackett G. Joint stabilization: an experimental, histologic study with comments on the clinical application in ligament proliferation. Am J Surg 1955; 89: 968-73.

[180] Kim HJ, Kim SH, Yun DH, Lee KS, Jeong TS. The effects of antiinflammatory drugs on histologic findings of the experimental prolotherapy model. J Korean Acad Rehabil Med 2006; 30: 378-84.

[181] Reeves KD. Prolotherapy: injection of growth factors or growth factor production stimulants to growth normal cells or tissue. In: Waldman SD, Ed. Pain Management. Philadelphia: Elsevier 2006; pp. 1106-27.

[182] Liu YK, Tipton CM, Matthes RD, Bedford TG, Maynard JA, Walmer HC. An in situ study of the influence of a sclerosing solution in rabbit medial collateral ligaments and its junction strength. Connect Tissue Res 1983; 2: 95-102.

[183] Jensen KT, Rabago DP, Best TM, Patterson JJ, Vanderby R Jr. Response of knee ligaments to prolotherapy in a rat injury model. Am J Sports Med 2008; 36: 1347-57.

[184] Klein RG, Dorman TA, Johnson CE. Proliferant injections for low back pain: histologic changes of injected ligaments and objective measures of lumbar spine mobility before and after treatment. J Neurol Orthop Med Surg 1989; 10: 141-4.

[185] Harman R, Cowles B, Orava C. A retrospective review of 62 cases of suspensory ligament injury in sport horses treated with adipose derived stem and regenerative cell therapy. Proceedings of the Veterinarian Orthopedic Society, March 3-10; Sun Valley 2006.

[186] Dahlgren LA. Use of adipose derived stem cells in tendon and ligament injuries. American College of Veterinarian Surgery Symposium on Equine Small Animal Proceedings 2006; pp. 150-1.

[187] Hackett G. Shearing injury to the sacroiliac joint. J Int Coll Surg 1954; 22: 631-42.

[188] Lee JD, Lee DW, Jeong CW, Kim WM, Lee HG, Yoon MH. Effects of intraarticular prolotherapy on sacroiliac joint pain. Korean J Pain 2009; 22(3): 229-33.

[189] Cusi M, Saunders J, Hungerford B, Wisbey-Roth T, Lucas P, Wilson S. The use of prolotherapy in the sacroiliac joint. Br J Sports Med 2010; 44: 100-4.

[190] Hackett G. Back pain following trauma and disease- Prolotherapy. Mil Med 1961; 126: 517-25.

[191] Hackett G. Low back pain. Br J Phys Med 1956; 19: 25-35.

[192] Hooper RA, Frizzel JB, Faris P. Case series on chronic whiplash related neck pain treated with intraarticular zygapophysial joint regeneration injection therapy. Pain Physician 2007; 10: 313-8.

[193] Centeno CJ, Elliott J, Elkins WL, Freeman M. Fluoroscopically guided cervical prolotherapy for instability with blinded pre and post radiographic reading. Pain Physician 2005; 8: 67-72.

[194] Jo D, Ryu K, Yang S, Kim M. The effects of prolotherapy on shoulder pain. Korean J Anesthesiol 2004; 46: 589-92.

[195] Hauser RA, Hauser MA, Holian P. Hackett-Hemwall dextrose prolotherapy for unresolved elbow pain. Pract Pain Manage 2009; October: 14-26.

[196] Kim JM. The effect of prolotherapy for osteoarthritis of the knee. J Korean Acad Rehabil Med 2002; 26: 445-8. 
[197] Reeves KD, Hassanein KK. Randomized prospective double-blind placebo-controlled study of dextrose prolotherapy for knee osteoarthritis with or without ACL laxity. Altern Ther Health Med 2000; 6(2): 68-79.

[198] Hakala RV. Prolotherapy in the treatment of TMD. J Craniomandibular Pract 2005; 23: 1-6.

[199] Schultz L. A treatment of subluxation of the temporomandibular joint. JAMA 1937; 109(13): 1032-5.

[200] Reeves KD, Topol GA, Fullerton BD. Evidence-based regenerative injection therapy (prolotherapy) in sports medicine. In: Seidenberg
PH, Beutler PI, Eds. The Sports Medicine Resource Manual. Philadelphia: Saunders/Elsevier 2008; pp. 611-9.

[201] Hauser RA, Hauser MA. Prolo Your Sports Injuries Away! Oak Park, IL: Beulah Land Press 2001.

[202] Hildebrand KA, Frank CB, Hart DA. Gene intervention in ligament and tendon: current status. Challenges, future directions. Gene Ther 2004; 11: 369-78.

[203] Molloy T, Wang Y, Murrell G. The roles of growth factors in tendon and ligament healing. Sports Med 2003; 33(5): 381-94.

(C) Hauser et al.; Licensee Bentham Open.

This is an open access article licensed under the terms of the Creative Commons Attribution Non-Commercial License (http: //creativecommons.org/licenses/by$\mathrm{nc} / 3.0 /$ ) which permits unrestricted, non-commercial use, distribution and reproduction in any medium, provided the work is properly cited. 